\title{
Aging, Melatonin, and the Pro- and Anti-Inflammatory Networks
}

\section{Rüdiger Hardeland $\mathbb{B}$}

Johann Friedrich Blumenbach Institute of Zoology and Anthropology, University of Göttingen, 37073 Göttingen, Germany; rhardel@gwdg.de; Tel.: +49-551-395414

Received: 11 February 2019; Accepted: 7 March 2019; Published: 11 March 2019

check for updates

\begin{abstract}
Aging and various age-related diseases are associated with reductions in melatonin secretion, proinflammatory changes in the immune system, a deteriorating circadian system, and reductions in sirtuin-1 (SIRT1) activity. In non-tumor cells, several effects of melatonin are abolished by inhibiting SIRT1, indicating mediation by SIRT1. Melatonin is, in addition to its circadian and antioxidant roles, an immune stimulatory agent. However, it can act as either a pro- or anti-inflammatory regulator in a context-dependent way. Melatonin can stimulate the release of proinflammatory cytokines and other mediators, but also, under different conditions, it can suppress inflammation-promoting processes such as NO release, activation of cyclooxygenase-2, inflammasome NLRP3, gasdermin D, toll-like receptor-4 and mTOR signaling, and cytokine release by SASP (senescence-associated secretory phenotype), and amyloid- $\beta$ toxicity. It also activates processes in an anti-inflammatory network, in which SIRT1 activation, upregulation of Nrf2 and downregulation of NF- $\mathrm{KB}$, and release of the anti-inflammatory cytokines IL-4 and IL-10 are involved. A perhaps crucial action may be the promotion of macrophage or microglia polarization in favor of the anti-inflammatory phenotype M2. In addition, many factors of the pro- and anti-inflammatory networks are subject to regulation by microRNAs that either target mRNAs of the respective factors or upregulate them by targeting mRNAs of their inhibitor proteins.
\end{abstract}

Keywords: circadian; immunosenescence; inflammaging; melatonin; microRNAs; sirtuin-1

\section{Introduction}

Aging is associated with manifold changes. These comprise declined secretion of hormones such as melatonin [1,2], reduced activities of aging-related factors such as sirtuin-1 (SIRT1) [3], deterioration of the circadian oscillator system [4,5], multiple alterations in the immune system that is frequently shifted toward the proinflammatory side [6-10], and many more deviations of cell biological relevance. Importantly, the changes specifically mentioned are interrelated in multiple ways $[3,5,9,10]$. This is largely based on the pleiotropy of both melatonin [11] and the circadian system [12-14]. However, these relationships are highly complex, include actions in opposite directions, and cannot be interpreted in reductionist ways.

For example, the effects of melatonin in the immune system can be either pro- or anti-inflammatory [15-17]. Generally, melatonin acts as an immune stimulatory agent and the direction into which the balance is shifted has turned out to be highly conditional. The influence of melatonin on SIRT1 expression has also revealed effects of either down- or upregulation, in this case, with a remarkable difference between tumor and non-tumor cells [5]. While being strongly suppressive in cancer, melatonin mainly stimulated SIRT1 in nontransformed cells, especially in the context of aging. However, a considerable problem exists concerning the, unfortunately, prevailing determination of SIRT1 expression rather than activity. Assuming a correlation between expression and activity, which is questionable, is a profound misconception in the case of sirtuins [18]. Sirtuin activities are 
not primarily determined by their protein levels but rather by $\mathrm{NAD}^{+}$concentration, which depends on the activity of nicotinamide phosphoribosyltransferase (NAMPT) [19-22]. The contrast between SIRT1 expression and activity has become evident in a study on the effect of BRCA1 (breast cancer 1, early onset) in ovarian cancer [23]. Suppression of BRCA1 reduced SIRT1 expression, but it increased $\mathrm{NAD}^{+}$concentration and, therefore, SIRT1 activity. Moreover, BRCA1 overexpression upregulated SIRT1 expression and decreased $\mathrm{NAD}^{+}$levels and SIRT1 activity. This divergence also seems to be relevant to aging. SIRT1 expression was not generally shown to be decreased in the course of aging, but rather, it was shown to often increase. Nevertheless, SIRT1 activity was found to be reduced because of lowered $\mathrm{NAD}^{+}$levels $[24,25]$. However, this does not yet mean that positive correlations between SIRT1 expression and activity are generally excluded in the context of aging. In senescence-accelerated SAMP8 mice, SIRT1 expression was found to be reduced relative to the widely isogenic control strain SAMR1 [26]. Moreover, a number of studies have shown that effects of melatonin that increased SIRT1 expression were suppressed by sirtuin inhibitors such as sirtinol or EX527 [27-39]. Therefore, mandatory requirements are to either determine SIRT1 activity and NAD ${ }^{+}$ concentration (recommended) or to at least test the effects of sirtuin inhibitors [18].

The changes in melatonin secretion and SIRT1 activity also have a circadian dimension. Both of them are under circadian control and exhibit cycles of high amplitudes. Moreover, either of them can influence circadian oscillators. Apart from its known chronobiotic actions via the suprachiasmatic nucleus (SCN), melatonin also influences peripheral oscillators [40]. SIRT1 has been identified as an accessory oscillator component [19-21] that increases circadian amplitudes of both central and peripheral clocks [21,41]. At least one of the mechanisms described is of relevance for antagonizing age-related decreases in the amplitudes of the SCN output [41]. An additional aspect concerns the conclusion that SIRT1 acts as a partial mediator of melatonin effects [18,42]. Finally, it seems important to remain aware of the different phases of increases and decreases observed within a circadian cycle. It is basic knowledge of chronobiology that a specific treatment applied in different phases leads to different, often opposite, effects [5]. In the context of aging, additional difficulty results from the fact of non-identical changes observed between the populations of oscillators within the body. In a senescent mammal, some oscillators exhibit phase changes, others reduced amplitudes, in the extreme, down to arrhythmicity, whereas others remain widely unchanged [4]. Collectively, all these variabilities summarized here oppose any expectation of finding exclusively unidirectional relationships by applying melatonin, sirtuin overexpression, or other modulators of circadian rhythms.

These reservations also have to be kept in mind when considering the effects of melatonin and SIRT1 in the regulation of pro- and anti-inflammatory processes. These are of particular relevance to aging and age-related diseases, especially as proinflammatory mechanisms gain increasing importance in the course of senescence. The overlapping effects of melatonin and SIRT1 in the field of inflammation regulation will be discussed in this article.

\section{Melatonin and the Proinflammatory Network}

In the course of studies that revealed numerous effects of melatonin beyond the control of circadian oscillators, immunological actions of melatonin were also discovered [9,15,43-46]. However, the statement that melatonin possesses properties that exceed the control of oscillators does not mean that the resulting effects are independent of circadian rhythms. Both melatonin secretion and signaling are subjected to circadian control. Parameters affected, including immunological ones, are also influenced by the circadian system [11,47]. With regard to the immune system, the situation is somewhat more complicated as melatonin is also synthesized by several types of leukocytes $[11,44,48,49]$.

Many of the earlier investigations on melatonin in the immune system revealed proinflammatory effects, as repeatedly summarized $[11,15,17,44]$. Notably, these actions were predominantly discovered in studies using isolated leukocytes or transformed leukocyte-derived cell lines [16,17,44]. Although such an approach appears to be reasonable in the beginning, it may not sufficiently reflect the complexity of the immune system and the additional participation of, in classical terms, non-immune 
cells in both proinflammatory responses and the regulation of the pro-/anti-inflammatory balance. Data obtained in humans also indicated proinflammatory actions of melatonin in rheumatoid arthritis [50-52]. These findings were regarded as a general caveat concerning the use of the immune stimulator melatonin in autoimmune diseases. This view has received partial support by a study in a multiple sclerosis model [53]. Most of the earlier findings on proinflammatory effects in cell cultures concerned the upregulation of proinflammatory cytokines (IL-1 $\beta$, IL-2, IL-6, IL-8, IL-12, IFN $\gamma$, and TNF $\alpha$ ) and downregulation of their anti-inflammatory counterpart (IL-10), as summarized elsewhere $[15,16,44]$. Additionally, melatonin was shown to counteract the inhibition of IL-2 production by prostaglandin $\mathrm{E}_{2}$ in human lymphocytes [54].

However, this short overview of the inflammation-promoting effects does not yet sufficiently describe the actions of melatonin within the proinflammatory network. In fact, these actions also comprise numerous suppressive changes in this network and, thereby, can turn out to result in an anti-inflammatory balance. To appropriately judge the complex influences of melatonin, it is necessary to view it under these different, additional perspectives: (1) changes in tissues and their main cellular constituents; (2) cell specificity; (3) effects on clonal expansion, differentiation, and polarization in the immune system; (4) contributing proinflammatory effects of non-immune cells; and (5) conditionality, with regard to high-grade or low-grade inflammatory challenges that may occur in the progression of aging or by experimental procedures.

As recently summarized, melatonin-induced elevation of proinflammatory cytokines, such as IL-1 $\beta$, IL-2, IL-6, IL-12, TNF $\alpha$, and IFN $\gamma$, has been repeatedly observed in monocytes, monocyte-derived cell lines, and type 1 T-helper cells [17]. One can assume that similar responses occur in M1 macrophages, M1 microglia and, especially concerning IL-6, IL-8, and TNF $\alpha$, also in epithelial cells and various other cell types. Notably, these findings can be seen in the context of pro-oxidant and cytotoxic effects exerted by melatonin in monocytes, as observed above an activation threshold as low as $50 \mathrm{pM}$ [55]. Moreover, melatonin was found to increase another proinflammatory cytokine, IL-17A, in Th17 cells [56], an effect that spreads proinflammatory responses by inducing the release of other mediators, such as IL- $1 \beta, \mathrm{IL}-6, \mathrm{TNF} \alpha$, the neutrophil-attracting Il-8, and by upregulating cyclooxygenase-2 (COX-2) and iNOS (inducible NO synthase) [57-65]. This host of secondary effects by IL-17A has been shown to be involved in autoimmune diseases and in neuroinflammation and is, therefore, of relevance to age-related health problems and to adverse effects of melatonin, especially in autoimmunity. Additionally, melatonin was shown to upregulate IL-1 $\beta$, $\mathrm{TNF} \alpha$, and IFN $\gamma$ in splenocytes [66]. Several other effects of melatonin concern the upregulation of cytokines that are primarily involved in differentiation and clonal expansion, such as M-CSF (macrophage colony-stimulating factor) and SCF (stem cell factor) in macrophages and splenocytes, TGF $\beta$ (transforming growth factor) in macrophages and dendritic cells, and thymosin- $\alpha$ and thymulin in thymocytes, as summarized elsewhere [16]. Melatonin was shown to promote differentiation of progenitor cells to Th lymphocytes, NK lymphocytes, granulocytes, and macrophages $[16,44$, 45]. All these effects may have secondary consequences to the pro-/anti-inflammatory balance. In bone marrow, an upregulation of GM-CSF (granulocyte/monocyte colony-stimulating factor) may be interpreted in a similar way, but, on the other hand, melatonin-induced release of the immune-opioids MIO15 (melatonin-induced opioid) and MIO67 [16,67-69] can be expected to favor the anti-inflammatory side of the immune system.

The proinflammatory network comprises numerous components, which are regulated differently by melatonin. Moreover, the responses are often highly contextual. Findings obtained by applying pro-oxidant or proinflammatory challenges, such as administration of oxidotoxins, mitotoxins, bacterial lipopolysaccharides (LPS) or experimental sepsis, may not lead to results comparable to those found in aging. Therefore, it seems important to focus on changes that really occur in aging or age-related diseases and can be mostly classified as low-grade inflammation [10,17,70]. Several sources of aging-related inflammation shall be mentioned as being of foremost importance: (1) enhanced release of proinflammatory cytokines as a consequence of immunosenescence; (2) neuronal overexcitation in 


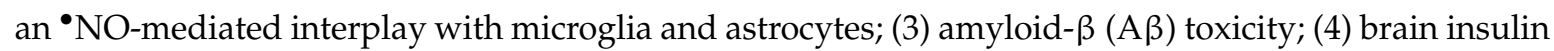
resistance; (5) diabetes and metabolic syndrome; (6) senescence-associated secretory phenotype (SASP) of non-immune cells with DNA damage response (DDR); (7) garb-aging; (8) reduced antioxidant protection by decreased melatonin; and, presumably, also (9) metabolic malfunction because of poorly coordinated and weakened circadian rhythms. Notably, all these pathophysiological alterations are associated with oxidative and nitrosative/nitrative stress and mitochondrial malfunction. They have multiple interconnections and, thereby, display the potential of forming vicious cycles $[10,17,70]$.

Immunosenescence, which is primarily associated with thymic involution and, additionally, exhaustion of leukocyte subpopulations upon lifelong exposure to foreign antigens, typically leads to a shift toward a proinflammatory phenotype, which is evident by increased levels of proinflammatory cytokines that may result in a so-called immune risk profile $[7,10,70-73]$. Neuronal overexcitation causes increased formation of ${ }^{\bullet} \mathrm{NO}$, which can activate microglia, astrocytes, and other neurons that also release ${ }^{\bullet} \mathrm{NO}$ at elevated rates. These responses contribute to a spreading of excitation and to the release of oxidants and proinflammatory mediators, especially by microglia. High levels of ${ }^{\bullet} \mathrm{NO}$ and superoxide anions $\left(\mathrm{O}_{2}{ }^{--}\right)$generate the formation of their adduct, peroxynitrite $\left(\mathrm{ONOO}^{-}\right)$, a highly reactive intermediate that causes damage to mitochondria and additionally generates free radicals $\left(\mathrm{ONOO}^{-}+\mathrm{H}^{+} \rightarrow \mathrm{ONOOH} \rightarrow{ }^{\bullet} \mathrm{NO}_{2}+{ }^{\bullet} \mathrm{OH} ; \mathrm{ONOO}^{-}+\mathrm{CO}_{2} \rightarrow \mathrm{ONOOCO}_{2}^{-} \rightarrow{ }^{\bullet} \mathrm{NO}_{2}+\right.$ $\mathrm{CO}_{3}{ }^{--}$) [74,75]. These radicals, their precursors, and several other reactive nitrogen species that can be formed from them interfere with the mitochondrial electron transport chain (ETC) [74,76,77]. As recently summarized, melatonin protects the ETC against these reactive intermediates [77], in addition to various other mitochondria-protecting actions [78-83]. A $\beta$ peptides have, besides other effects, pro-oxidant and proinflammatory properties. The main toxicity is caused by A $\beta$ monomers and oligomers, with an additional contribution by amyloid plaques. Peptides and oligomers induce microglia activation [84,85] and, additionally, responses by astrocytes [86] and neurons [86,87], which all upregulate NADPH oxidase, thereby elevating $\mathrm{O}_{2}{ }^{\bullet-}$ formation. Notably, the release of proinflammatory mediators in response to $A \beta$ is not restricted to microglia. Even neurons have been shown to respond to A $\beta$ peptides by upregulating TNF $\alpha$, IL-1 $\beta$, COX-2, and the T-cell and monocyte attractant chemokine CX3CL1 [87]. A $\beta$ toxicity should not only be seen in the context of established Alzheimer's disease (AD), since these peptides also appear in the CSF (cerebrospinal fluid) of healthy subjects, but are normally widely removed by clearance of CSF and ISF (interstitial fluid), especially during sleep [88-91]. Sleep disturbance impairs A $\beta$ clearance, which has been discussed as a contribution to the development of $\mathrm{AD}$ pathology [92]. Circadian disruption, a major source of sleep disturbances, indicates that changes in melatonin secretion may be involved. In fact, melatonin has been recently shown to increase $A \beta$ clearance $[93,94]$. Numerous other anti-amyloidogenic effects of melatonin have been also described and repeatedly reviewed [70,95-98]. A recent overview [17] has particularly focused on the anti-inflammatory aspect and the suppression of $A \beta$ secretion by melatonin. This includes, in cellular test systems, the reduction of $\beta$ APP ( $\beta$-amyloid precursor protein) mRNA expression [99], inhibition of $\beta$ - and $\gamma$-secretases [100], and the upregulation of $\alpha$-secretase, an enzyme that competes with $\beta$ - and $\gamma$-secretases and produces the nonamyloidogenic and neuroprotective fragment $\operatorname{sAPP} \alpha$ [101]. The shift from $\beta$ - and $\gamma$-secretases to $\alpha$-secretase was recently also confirmed in the hippocampus of senescent mice [102,103]. In transgenic AD mouse models, melatonin was found to substantially delay the accumulation of $A \beta$ and to extend lifespan $[104,105]$. However, this was only observed after an early onset of treatment in the first months of life, but not at later age [106], findings that leave a pessimistic perspective for the treatment of humans. Another, surprising nexus to $\mathrm{AD}$ pathology and inflammation emerged, when brain insulin resistance was shown to be an early sign of neuroinflammation at the onset of $\operatorname{AD}[107,108]$. For further details and references, see $[17,109]$. This aspect remains to be studied in the context of melatonin, but would require a strict discrimination between nocturnal rodents and humans, since the disregard of this difference has led to substantial misinterpretations concerning the beneficial or detrimental role of melatonin in type 2 diabetes $[5,16]$. Also, beyond the CNS, type 2 diabetes and, in a broader sense, metabolic syndrome, are associated 
with low-grade inflammation, a phenomenon known under the term of metaflammation [110-112], which contributes to inflammaging [111,112]. Numerous beneficial effects of melatonin in metabolic syndrome have been recently summarized [113], which have been observed in both experimental animals and clinical studies and indicate a reduction of metaflammation.

Another aspect of proinflammatory effects concerns the role of non-immune cells in inflammaging. This comprises mainly three processes, SASP, garb-aging, and release of macromolecules from dying cells. In SASP, DNA-damaged cells are arrested in terms of proliferation, but continue to participate in the metabolism of the tissue. However, they release several signal molecules, including proinflammatory cytokines and chemokines, thereby inducing local, low-grade inflammation [114-118]. SASP has been observed in many cells of peripheral tissues, but also in astrocytes and is, therefore, relevant to the CNS $[70,119,120]$. Notably, SASP has also been shown to be induced by sleep disruption [121]. As this was associated with increased oxidative stress, the observed changes may comprise a chronodisruption-related nocturnal loss of protection by melatonin. Studies on direct effects of melatonin against SASP are still in their infancy, but recent initial results have described this [122-124]. In mechanistic terms, melatonin was shown to suppress the PARP-1 [poly(ADP-ribose) polymerase-1]-induced expression of SASP genes [122]. Whether or not this role of PARP-1 can be generalized remains to be clarified, since this regulator, which is an indicator of DNA damage, has also been interpreted as an epigenomic safeguard that interferes with SASP-associated microRNAs [125]. In another context, melatonin was reported to suppress SASP by downregulating NF- $\mathrm{KB}$ and upregulating Nrf2 (nuclear factor erythroid 2-related factor 2) [124], i.e., two known effects of melatonin that are typically observed in mechanisms of antioxidative and anti-inflammatory protection $[17,126]$. Other sources of low-grade inflammation by non-immune cells, such as garb-aging [127] and release of components of dying cells such as histone H1 [128] and molecules of mitochondrial origin (nucleic acids, $N$-formylated peptides and proteins) to the cytosol [129-132], are presumably also of substantial relevance to inflammaging, but have not been sufficiently studied in relation to melatonin. Nevertheless, this connection exists with high likelihood with regard to mitochondrial DNA (mtDNA), especially if it is damaged or oxidized. Activation of the NLRP3 inflammasome by mtDNA has been repeatedly described, whereas counteractions by melatonin have been multiply documented and reviewed, as summarized elsewhere [133]. Melatonin administration was shown to be as effective as NLRP3 deficiency [134]. Unfortunately, the important proinflammatory pathway of cGAS/STING (cyclic GMP-AMP synthase/stimulator of IFN genes) signaling has, to date, been poorly considered in melatonin research. This would be of particular interest, as cGAS is a cytosolic DNA detector. Moreover, the depletion of cGAS and STING counteracted cell senescence and prevented SASP in human and murine fibroblasts [135]. cGAS appears as a mediator of cell stress reactions and has been assumed to be involved in aging-related diseases [131]. This interpretation has received support by recent findings on a human Sting gene polymorphism that is associated with low-risk of aging-related diseases, presumably by reducing inflammaging [136].

Activation of the NLRP3 inflammasome in various systems, under different conditions and counteractions by melatonin, have been recently reviewed [17]. These findings were widely related to the suppression of NF- $\mathrm{kB}$ signaling by melatonin, which is likewise important in the attenuation of oxidative damage [126]. NF- $\mathrm{kB}$ was also reported to induce pyroptosis via gasdermin D (GSDMD) in adipose tissue, which was likewise inhibited by melatonin [137]. Other inflammation-related and melatonin-sensitive effects of NF-KB concern the upregulation of iNOS and COX-2 [138-141]. Moreover, in the context of presenilin-1 upregulation and pathogenic $\beta$ APP processing, a pathway involving PIN1 (peptidyl-prolyl cis-trans isomerase NIMA-interacting 1) and GSK3 $\beta$ (glycogen synthase kinase $3 \beta$ ) was shown to activate NF- $k B$, which was, in accordance with many other findings on NF- $\mathrm{kB}$ suppression, inhibited by melatonin [142].

Another proinflammatory route is based on TLR4 (toll-like receptor 4) activation, e.g., via the IFN $\gamma$ adaptor protein, TRIF (toll-receptor-associated activator of interferon). In the macrophage-like cell line RAW264.7, melatonin has been shown to suppress the release of proinflammatory cytokines, 
such as TNF $\alpha$, IL-1 $\beta$, IL-6, and IL-8, by TRIF and TLR4 inhibition [143]. As TLR4 also mediates pro-oxidant actions via NF- $\mathrm{kB}$, more general effects by melatonin on this pathway may be assumed. This conclusion is supported by several pertinent findings describing protection by melatonin [17]. Similar anti-inflammatory effects were also obtained in an in vivo model of ovarian cancer [144]. Information on melatonin effects concerning other TLR subforms is still scarce. No effects were found in a single study on TLR2 [144], whereas inhibition of TLR3 was reported $[145,146]$.

A further possible proinflammatory pathway that is inhibited by melatonin concerns mTOR (mechanistic target of rapamycin) activation. However, most respective information is not directly related to inflammation, but rather to mitophagy or apoptosis. Interestingly, an mTOR inhibiting action by melatonin was also shown to be suppressed by inhibition of PIN1 [123]. Moreover, the attenuation of microglial activation and neuroinflammation after traumatic brain injury by melatonin was also interpreted on the basis of interference with mTOR [147]. This route will be of further interest in the specific context of melatonin's anti-inflammatory actions.

\section{Melatonin, SIRT1, and the Anti-Inflammatory Network}

While melatonin is partially acting by either stimulating or inhibiting components of the proinflammatory network, it also upregulates molecules of an anti-inflammatory network. Some of them are negatively correlated with proinflammatory agents. For instance, NF- $\mathrm{kB}$, a transcription factor involved in prooxidant and, thereby, proinflammatory responses, is inversely coupled to antioxidant and anti-inflammatory regulators, in particular, $\mathrm{Nrf2}[17,126,139,148-151]$. A similar correlation seems to exist in the case of PARK7 (parkinsonism associated deglycase; also known as DJ-1) [149,150], a protein that acts, beside other effects, as a redox-sensitive chaperone and stress sensor. In Parkinson's disease (PD), it has been shown to be neuroprotective [152].

An especially important anti-inflammatory regulator under control by melatonin is SIRT1. It has been classified as a secondary signaling molecule that mediates several effects of melatonin [18,42]. In non-tumor cells, it has been shown to be upregulated by melatonin and effects by melatonin have been repeatedly reported to be suppressed by sirtuin inhibitors or Sirt1 siRNA [5], notably also in an anti-inflammatory context [17]. The relationship between melatonin and SIRT1 may be regarded as a mutual one, since SIRT1 can enhance circadian amplitudes in the SCN [41] and may, thereby, influence the melatonin rhythm [3]. With this background, the functional overlap of described melatonin and SIRT1 actions seems worthwhile to be recalled.

This overlap becomes obvious from two lines of evidence, (1) the interference of sirtuin-related agents with melatonin effects, and (2) similar actions of melatonin and SIRT1. In the former context, reductions of NLRP3 inflammasome activation and IL-1 $\beta$ levels by melatonin were blocked by the sirtuin inhibitor EX527 in a rat COPD (chronic obstructive pulmonary disease) model [39]. The same inhibitor also blocked anti-inflammatory actions of melatonin such as downregulation of TNF $\alpha$ and IL-1 $\beta$ in acute kidney injury of rats [36]. Several other results on sirtuin inhibition of melatonin treatment were obtained under conditions of more severe inflammation. This was observed in cardiac ischemia/reperfusion of normal [30] and diabetic rats [31], correspondingly in ER stress of H9C2 cardiomyocytes [31], in LPS-treated microglial cell lines [37], and in brain injury by cecal ligation/puncture in mice [32]. Further studies, without measurement of inflammatory parameters, in which melatonin effects were blunted by sirtuin inhibitors or Sirt1 siRNA, are summarized elsewhere [5,17].

Numerous studies have demonstrated antioxidant and anti-inflammatory actions by SIRT1 that are also known from melatonin [17]. This concerns the suppression of NF-KB activation [153-156], the upregulation of Nrf2 [157-161], suppression of NLRP3 inflammasome activation [39,162-165], and inhibition of TLR4 signaling [166-168]. An important player in TLR4 activation is HMGB1 (high mobility group box-1), an inflammatory signaling molecule released by monocytes and macrophages, and also by other cells (e.g., endothelial). SIRT1 is known to deacetylate HMGB1 $[169,170]$, to inhibit its nucleocytoplasmic transfer, and to prevent its release $[167,171-176]$. Importantly, HMGB1 also favors 
the polarization of macrophages and microglia towards the proinflammatory M1 type [177-181]. With regard to the melatonin-SIRT1 relationship, it is of interest that anti-inflammatory actions via HMGB1 inhibition have been also reported for melatonin, as recently summarized [17]. Again, SIRT1 may mediate melatonin effects in this case, an assumption to be experimentally confirmed.

SIRT1 also displays several additional anti-inflammatory effects, which cannot yet be matched with corresponding data from melatonin treatment. As mentioned in the previous section, some reports on melatonin effects on mTOR signaling have not been directly related to inflammation. Other studies on actions of melatonin on mTORC1 (mTOR complex 1) activity in cancer cells led to contradictory results [182-184] and, therefore, do not provide a reliable basis for comparison. However, SIRT1 has been shown to counteract adipose inflammation by suppressing mTORC1 signaling [185]. Another investigation on liver steatosis reported an increase of mTORC1 activity upon hepatocyte-specific deletion of SIRT1 [186]. Under conditions of sepsis, SIRT1 was also reported to deacetylate and, thereby, inhibit NICD (intracellular domain of Notch) [187,188]. Apart from its developmental roles, Notch is known to act in a proinflammatory way by promoting M1 polarization of macrophages or related cells. Conversely, SIRT1 knockdown upregulated Notch1 in stellate cells at both mRNA and protein levels [189]. However, the relationship to melatonin remains unclear because beneficial effects of Notch signaling were reported in studies on protection against ischemia/reperfusion and A $\beta$ toxicity by melatonin [190-192], in spite of the fact that Notch activation is known to cause inflammatory responses. Either the endpoints studied were unrelated to macrophages or microglia, respectively, or Notch signaling may be a case in which SIRT1 does not mediate melatonin effects. This would be surprising, as melatonin was shown to upregulate SIRT1 under conditions of ischemia/reperfusion, and as some of the melatonin effects were blocked by EX527 or Sirt1 siRNA [5,30,31].

Another recently reported anti-inflammatory action of SIRT1 has been observed in macrophages after treatment with LPS. The lncRNA-CCL2, which is related to the gene locus of the chemokine CCL2 and stimulates the release of proinflammatory cytokines, was downregulated by SIRT1 [193]. No corresponding data on changes of IncRNA-CCL2 expression by melatonin are actually available.

Despite the fact that many proinflammatory effects of melatonin are mediated by lymphocytes $[15,44,49,54,56]$, such responses were also obtained in monocytes and monocyte-derived cells $[11,15,44]$. However, as macrophages and related cells represent major executive players in inflammation, their polarization into proinflammatory M1 or anti-inflammatory M2 phenotypes is of utmost importance for the pro-/anti-inflammatory balance. In fact, melatonin is capable of shifting this balance toward the anti-inflammatory side by favoring M2 and disfavoring M1 polarization, as recently reviewed [194]. One of the major anti-inflammatory effects in the inhibition of M1 function consists in the $\mathrm{MT}_{1}$ receptor-mediated activation of JAK2 (Janus kinase 2), which phosphorylates STAT3 (signal transducer and activator of transcription 3) [194-197]. In the nucleus, pSTAT3 dimers activate SOCS1 (suppressor of cytokine signaling 1), which favors NF- $\mathrm{B}$ B degradation by virtue of its property as an E3 ubiquitin ligase and, thus, inhibits NF-KB actions at the chromatin [194,198-200]. Additionally, suppression of NF-KB actions has been reported for $\operatorname{ROR} \alpha[194,201]$. This relationship is highly convincing, since ROR $\alpha$ knockout causes strong upregulations of proinflammatory cytokines [202]. However, as ROR $\alpha$ has been definitely shown to be incapable of binding melatonin [203,204], actions of melatonin via this transcription factor have to be of indirect nature $[18,194]$. A possibility of particular interest concerns an effect of SIRT1 on $\operatorname{ROR} \alpha$, in its function as a partial mediator of melatonin effects. As far as melatonin upregulates SIRT1, a known mechanism can become effective, which comprises deacetylation of PGC- $1 \alpha$ (peroxisome proliferator-activated receptor- $\gamma$ coactivator- $1 \alpha$ ) and facilitates the binding of ROR $\alpha$ to its response elements (ROREs) [41]. With regard to the number of documented anti-inflammatory actions of SIRT1 summarized above, this idea is insofar attractive as SIRT1 was shown to suppress NF-kB signaling, as likewise reported for ROR $\alpha$ [153-155]. This does not exclude additional actions of SIRT1, which was also found to be involved in SOCS1 signaling [205].

M2 polarization of macrophages, and presumably in similar ways of microglial cells, is largely promoted by STAT6 phosphorylation, in pathways regulated by melatonin and anti-inflammatory 
cytokines, especially IL-4 and IL-13 [194]. A key step in these processes is tyrosine phosphorylation of IRS-2 (insulin receptor substrate 2), which can be achieved in multiple ways [194]: (1) via IL-4 or IL-13 binding to IL-4 receptor- $\alpha$, phosphorylation of JAK1/3 or JAK1/Tyk2 (tyrosine kinase-2), which may cause tyrosine phosphorylation of STAT6 directly or, alternately, IRS-2, followed by GRB2 (growth factor receptor bound-2) activation and STAT6 phosphorylation, or (2) via melatonin and an $\mathrm{MT}_{1 / 2}$-dependent cascade of pIRS-2, GRB2, and pSTAT6. pSTAT6 dimers are responsible for M2-specific gene expressions, partially in conjunction with KLF4 (krüppel-like factor 4), which interacts with pSTAT6. Additional effects of melatonin seem to contribute, such as $\mathrm{MT}_{1 / 2}$-dependent inhibition of PI3K (phosphoinositide 3-kinase), thereby blocking the proinflammatory Akt/mTORC1 cascade [194]. Moreover, this inhibitory effect of melatonin can be assumed to prevent two other negative modulatory actions, (1) by the mTORC1 downstream factor GRB10 and (2) by p70S6K (p50S-6-kinase). Tyrosine phosphorylation of IRS-2 and expression of M2 genes were found to be substantially increased by GBR10 knockdown [206]. Serine phosphorylation of IRS-2 by p70S6K was shown to counteract M2 polarization [206].

\section{Modulation of the Networks by Noncoding RNAs, an Emerging Field}

The discovery of countless noncoding RNAs (ncRNAs) with regulatory properties has substantially changed our understanding of regulation. Many of these RNAs interfere with posttranscriptional processes. This is especially the case in most microRNAs (miRNAs), which target mRNAs, and snoRNAs (small nucleolar RNAs), which are involved in RNA processing [207,208]. Other categories of RNAs such as eRNAs (enhancer RNAs) or super-enhancer lncRNAs (super enhancer long noncoding RNAs) directly interact with the chromatin and even with DNA [209]. piRNAs (PIWI-interacting RNAs) silence transposable elements via both transcriptional and posttranscriptional mechanisms [210]. Multiple functions are known for lncRNAs, in addition to enhancer properties. They may either positively or negatively regulate gene expression, which has been even observed in their subgroup of asRNAs (antisense RNAs). Moreover, various lncRNAs are precursors of miRNAs or snoRNAs [209]. Moreover, many lncRNAs and circRNAs (circular RNAs) serve as miRNA sponges and gain particular relevance in the transmission of intercellular signals by exosomes and ectosomes [209,211,212]. With regard to melatonin, numerous ncRNAs of different categories were shown to be influenced by this pleiotropic regulator [209,213-215]. As ncRNAs also modulate inflammation, macrophage activities, and NF- $\mathrm{KB}$ signaling [216-219], the relationship to melatonin is of particular interest and will certainly gain increasing future importance.

A complete consideration of all ncRNAs with positive or negative actions on inflammation would go beyond the scope of this article. A comprehensive list of miRNAs that affect pro- or anti-inflammatory cytokines has been recently published [220]. With regard to the melatonin-related task of this review, only those ncRNAs shall be discussed that are influenced by melatonin or change its downstream factors or interfere with major regulatory parts of the networks, especially if they concern areas of action known to be a matter of beneficial actions by melatonin, such as sepsis, ischemia/reperfusion, aging, or neurodegeneration. Findings obtained in the field of microRNAs are summarized in Table 1. Only those miRNAs have been considered that are related to the field of inflammation regulation. Many additional studies have revealed effects of melatonin on other miRNAs [214,221,222]. However, the outcome in a non-inflammatory context cannot be expected to be the same. This concerns especially the situation in cancer, although cancer can also have an inflammatory aspect. The major difference between non-tumor and tumor cells concerns the inverse relationship between melatonin and SIRT1 and the pro-apoptotic activity of melatonin in tumor cells $[5,16,17]$. One of the most extensive studies on melatonin effects on miRNAs [221] that has been omitted from Table 1 has been conducted in breast cancer cell lines. The determinations revealed 12 miRNAs that were upregulated by melatonin and 10 others that were downregulated. The analysis of their $5^{\prime}$-utr sequences indicated that these 22 miRNAs might target 2029 mRNAs. 
Table 1. Regulation of microRNA expression by melatonin and effects of microRNAs on SIRT1, Nrf2, and NF- $\mathrm{B}$ in the context of inflammation.

\begin{tabular}{|c|c|c|c|c|c|c|}
\hline miRNA & $\begin{array}{l}\text { Change by } \\
\text { Melatonin }\end{array}$ & Effect on Sirt1 & Effect on Nrf2 & $\begin{array}{l}\text { Nrf2-Related } \\
\text { Target }\end{array}$ & Effect on NF-KB & $\begin{array}{c}\text { NF-кB-Related } \\
\text { Target }\end{array}$ \\
\hline miR-7 & & $\downarrow ?[223]$ & $\uparrow[224]$ & Keap1 & $\downarrow[225,226]$ & \\
\hline miR-7-5p & & & & & $\downarrow[227]$ & \\
\hline miR-9 & & $\downarrow[228-236]$ & & & $\downarrow[236-242]$ & \\
\hline miR-9 & & & & & $\uparrow[243,244]$ & $\begin{array}{l}\text { MCPIP1, } \\
\text { TRIM56 }\end{array}$ \\
\hline miR-20a & & & & & $\uparrow[245,246]$ & CYLD \\
\hline miR-21 & & $\downarrow[247]$ & & & & \\
\hline miR-23a & $\downarrow[194,248]$ & $\downarrow[249-251]$ & $\uparrow[252]$ & Keap1 & $\uparrow[194]$ & \\
\hline miR-23a-3p & & $\downarrow[253]$ & & & & \\
\hline miR-23b & & $\downarrow[249]$ & & & & \\
\hline miR-23b-3p & & $\downarrow[155,254]$ & & & & \\
\hline miR-24 & $\downarrow[255]$ & $\uparrow[256]$ & & & & \\
\hline $\mathrm{miR}-24-3 p$ & & & $\uparrow[257]$ & Keap1 & & \\
\hline miR-26a & & & & & $\downarrow[258]$ & \\
\hline miR-27b & & & & & $\downarrow[259]$ & \\
\hline miR-29 & & $\downarrow[260]$ & $\uparrow[261,262]$ & Keap1 & & \\
\hline miR-30a & $\uparrow[263]$ & $\downarrow[264]$ & & & $\downarrow[265]$ & \\
\hline miR-30a-3p & & $\downarrow[266,267]$ & & & & \\
\hline miR-30e-5p & $\downarrow[268]$ & & & & & \\
\hline miR-31 & & & & & $\downarrow[269]$ & TRADD \\
\hline miR-34a & $\downarrow[270]$ & $\downarrow[271-275]$ & & & & \\
\hline miR-34a-5p & & $\downarrow[276]$ & & & & \\
\hline miR-101 & & & $\downarrow[277]$ & & & \\
\hline $\mathrm{miR}-106 \mathrm{a} / \mathrm{b}$ & & $\downarrow[278]$ & & & & \\
\hline miR-124a & & $\downarrow[279]$ & & & & \\
\hline $\mathrm{miR}-125 \mathrm{a} / \mathrm{b}$ & & & & & $\uparrow[280-284]$ & A20 \\
\hline $\mathrm{miR}-125 \mathrm{~b}$ & & & & & $\downarrow$ [285-289] & TRAF, MIP- $1 \alpha$ \\
\hline miR-126 & $\uparrow[270]$ & $\uparrow[290]$ & & & $\uparrow$ [291-293] & TOM1, IкB \\
\hline $\mathrm{miR}-128$ & & $\downarrow[294-296]$ & & & $\uparrow[297,298]$ & I $\kappa \mathrm{B}$ \\
\hline miR-132 & & $\downarrow[249]$ & & & & \\
\hline miR-135a & & $\downarrow[228]$ & & & & \\
\hline miR-142-3p & $\uparrow[299]$ & & & & & \\
\hline miR-144 & & & $\downarrow[300]$ & & & \\
\hline miR-145-5p & & $\downarrow[276]$ & & & & \\
\hline miR-146a & $\uparrow[270]$ & & $\downarrow[301]$ & & $\uparrow$ [302-305] & TRAF6, IRAK1 \\
\hline miR-150 & & & & & $\downarrow[306-309]$ & \\
\hline miR-152 & $\downarrow[310]$ & $\downarrow[256]$ & & & & \\
\hline miR-153 & & & $\downarrow[300]$ & & & \\
\hline miR-155 & $\downarrow[194,310]$ & $\downarrow[279,311,312]$ & $\uparrow[313,314]$ & & & \\
\hline miR-181a-c & & $\downarrow[228,230,315]$ & & & & \\
\hline miR-182 & & $\downarrow[316]$ & & & $\uparrow[317-320]$ & CYLD, TCEAL7 \\
\hline miR-195-5p & & $\downarrow[276]$ & & & & \\
\hline miR-199b & & $\downarrow[228]$ & & & & \\
\hline miR-200a & $\uparrow[321,322]$ & $\downarrow[189,323-327]$ & $\uparrow$ [328-336] & Keap1 & $\uparrow[337]$ & \\
\hline miR-200a-3p & & $\downarrow[276,338,339]$ & & & & \\
\hline miR-204 & & $\downarrow[228]$ & & & & \\
\hline
\end{tabular}


Table 1. Cont.

\begin{tabular}{|c|c|c|c|c|c|c|}
\hline miRNA & $\begin{array}{l}\text { Change by } \\
\text { Melatonin }\end{array}$ & Effect on Sirt1 & Effect on Nrf2 & $\begin{array}{c}\text { Nrf2-Related } \\
\text { Target }\end{array}$ & Effect on NF- $k B$ & $\begin{array}{c}\text { NF-кB-Related } \\
\text { Target }\end{array}$ \\
\hline miR-210 & & & & & $\downarrow[340,341]$ & DR6 \\
\hline miR-217 & & $\downarrow[345]$ & & & & \\
\hline miR-301a & & & & & $\uparrow[346-350]$ & NKRF \\
\hline miR-340-5p & & & $\downarrow[155,300,353]$ & & & \\
\hline miR-495 & & $\downarrow[354]$ & & & & \\
\hline miR-675 & $\uparrow[355]$ & & & & & \\
\hline miR-675-3p & $\uparrow[322]$ & & & & & \\
\hline Let-7e & & & & & $\uparrow[358]$ & IKB $\beta$ \\
\hline Let-7f & & & & & $\uparrow[359]$ & A20 \\
\hline Let-7g & & & & & $\uparrow[360]$ & \\
\hline Let-7i & & $\downarrow[361]$ & & & $\uparrow[361]$ & SIRT1 \\
\hline
\end{tabular}

Abbreviations: A20, ubiquitin-editing enzyme A20 (=TNFAIP3, tumor necrosis factor alpha-induced protein 3); BCL2A1, B-cell lymphoma 2A1; CYLD, cylindromatosis; DR6, death receptor 6; IRAK1, interleukin-1 receptor-associated kinase 1; KEAP1, Kelch-like ECH-associated protein 1; MCPIP1, monocyte chemotactic protein-induced protein 1 ; MIP- $1 \alpha$, macrophage inflammatory protein- $1 \alpha$; NKRF, NF- $\kappa B$ repressing factor; TCEAL7, Transcription elongation factor A protein-like 7; TOM1, target of Myb1; TRADD, tumor necrosis factor receptor type 1-associated DEATH domain protein; TRAF6, tumor necrosis factor receptor-associated factor 6; TRIM56, tripartite-motif-containing protein $56 . \downarrow \uparrow$ indicate down- or upregulations, respectively.

The pleiotropic targeting of various mRNAs by a single miRNA does not only open the possibility of jointly downregulating several mRNAs that are functionally connected, but may also reflect multiple functions in different contexts. This problem of overlapping actions of miRNAs with roles in both inflammation and cancer is also evident in the findings summarized in Table 1. Although the miRNAs were selected because of their modulation of inflammation, several of them exhibited other, perhaps independent, actions related to tumor promotion and progression. In fact, several molecules listed have been classified as oncomiRs, such as miR-21, miR-23a, miR-29, miR-106b, miR-125b, miR-155, and miR-182 [316,362-364].

The examples in Table 1, in which changes of miRNA expression by melatonin have been combined with actions of inflammation-related miRNAs on expression of SIRT1, Nrf2, and NF-kB, do not show a uniform picture. One of the reasons concerns the differences in context, cell types, and conditions, under which the studies have been performed. In many cases, changes by melatonin and effects on SIRT1, Nrf2, and NF-KB have been investigated in different systems. In a few cases, opposite effects have been obtained. In addition to organ specificity of melatonin actions, the difference between pro- and anti-inflammatory actions of melatonin has to be considered. The main purpose of this table is to provide information to investigators on which miRNAs they may focus on when studying melatonin effects in inflammation, especially in those cases where actions of melatonin on miRNAs have not yet been analyzed.

A few special types of connections between melatonin and the three possible downstream factors shall be briefly discussed. The levels of miR-7 have been shown to increase during aging, and it was assumed that it may downregulate SIRT1 [223]. On the other hand, the upregulation of Nrf2 and downregulation of NF-KB in the non-aging context of training athletes, which jointly indicate an antioxidant and anti-inflammatory action, is not easily compatible with reduced SIRT1 in senescence. In other cases of reduced SIRT1 expression, the reservation has to be made that decreased SIRT1 expression may be associated with elevated SIRT1 activity [23], as long as NAD ${ }^{+}$levels or inhibition by sirtuin inhibitors have not been determined. In reports in which upregulation by melatonin was 
associated with downregulation of SIRT1 (miR-30a) or Nrf2 and upregulation of NF-kB (miR-146a), this combination may be interpreted as a route of melatonin's proinflammatory arm. The example of miR-24, which is suppressed by melatonin, but enhances SIRT1 expression, may be taken as a tumor-specific relationship, because this would conform to melatonin's known suppression of SIRT1 in cancer cells $[5,365]$. Therefore, this may not be applicable to inflammation control. The presence of miR-126, which is upregulated by melatonin and increases SIRT1 expression, indicates a role of this sirtuin as a mediator of melatonin and may appear, at first glance, as an example of the anti-inflammatory route. However, this contrasts strongly with the upregulation of NF- $\mathrm{KB}$ and would require clarification by studying all these factors in the same system. A number of SIRT1-targeting miRNAs is downregulated by melatonin, such as miR-23a, miR-34a, miR-152, miR-155, miR-212, and, according to some but not all data, miR-200a. This reduction of SIRT1-suppressing miRNAs would, again, be compatible with findings on SIRT1-mediated melatonin effects $[17,18]$. Unfortunately, the findings concerning miRNA-mediated changes of NF- $\mathrm{kB}$ are, to date, often not generally compatible with the alterations in the other factors. Further studies will be required for obtaining a coherent picture. However, this reservation concerns only the participation of miRNAs, whereas the effects of melatonin and SIRT1 on Nrf2 and NF-KB have been unequivocally demonstrated [17].

Available information concerning melatonin effects on other noncoding RNAs is, unfortunately, limited. A few publications have addressed such actions on lncRNAs. In the case of the lncRNA H19, a relationship to miR-675 (cf. Table 1) exists, which is a derivative of the former. The effects of melatonin on $\mathrm{H}_{2} \mathrm{O}_{2}$-exposed cardiac progenitor cells correspond to those of the microRNA and, consequently, H19 knockdown abolishes the action of miR-675 [355]. The molecule miR-675 was shown to target USP10 (ubiquitin carboxyl-terminal hydrolase 10) mRNA, which was concluded to cause downregulation of p53 and p21, thereby inhibiting premature senescence by oxidative stress [355]. Upregulation of $H 19$ and miR-675 by melatonin was also observed in protection experiments against brain injury after subarachnoid hemorrhage [357]. In a study on pulmonary hypertension, melatonin reduced H19 expression and, therefore, also that of miR-675-3p, whereas H19 was shown to suppress miR-200a [322]. Meanwhile, numerous other studies have confirmed the role of H19 in inflammatory processes (not cited), however, they did not consider melatonin. Another type of interaction between lncRNA and miRNA was based on sponging. The lncRNA MEG3 was reported to enhance pyroptosis in atherosclerotic models, such as human aortic endothelial cells exposed to oxidized LDL (low density lipoprotein). MEG3 was found to sponge miR-223 and to activate NLRP3, whereas melatonin was shown to reduce pyroptosis by suppressing NLRP3 activation and downstream factors, such as NF- $\mathrm{kB}$, gasdermin D, IL-1 $\beta$, and IL-18 [366]. In hair follicle fibroblasts of cashmere goats, melatonin upregulated the IncRNA MTC, which was associated with proliferation and also NF- $\mathrm{kB}$ activation [367]. This finding was in contrast to many other results on NF- $\mathrm{KB}$ suppression by melatonin obtained in the context of antioxidant actions. Two other reports have dealt with melatonin's actions in hepatocellular carcinomas. In one study, melatonin was shown to reduce cancer progression by upregulating FoxA2, which induced the IncRNA CPS1-IT1, with a downstream effect of reduced HIF-1 $\alpha$ activity [368]. In another investigation, melatonin suppressed DNA repair capacity by upregulating the antisense lncRNA RAD51-AS1, which interacts with RAD51 mRNA, and the findings were interpreted as a sensitization to chemotherapeutic drugs [369]. A functionally different lncRNA, TERRA (telomeric repeat-containing RNA), has been investigated in the context of melatonin. This RNA interacts with PARP-1 (polyADP-ribose polymerase-1), a sensor of DNA damage. This interaction was shown to stimulate SASP, but melatonin suppressed SASP-related gene expression and, therefore, an important aging-promoting process [122].

Work on the mediation of melatonin effects on lncRNAs can be expected to become highly important in the future [198,370], although this line of investigation is still in its infancy. This assumption is also based on the increasing body of evidence in related fields, in particular, the circadian system $[209,371]$ and gerontology [372,373]. Numerous lncRNAs, e.g., over 600 in murine liver, were found to vary in a circadian fashion, often at very high amplitudes [371]. It would be a 
surprise if the chronobiotic regulator melatonin would not modulate at least a fraction of them. Among the IncRNAs, particular attention should be paid to subforms of a different functionality, such as asRNAs, eRNAs and, importantly, super-enhancer lncRNAs, all of which contain numerous species under circadian control [209,371]. The prominent role of lncRNAs in the control of inflammation has also become evident and has been reviewed multiple times [374-380]. In this context, more research on melatonin is desired. A further category of RNAs that will gain importance in the melatonin field, but are still devoid of pertinent investigations, are the circRNAs, which are known to sponge miRNAs [211,381-383]. With regard to a miRNA discussed above, miR-7, which is sponged by the circRNA CDR1as (alias ciRS-7), a few recent publications indicate relationships to NF- $\mathrm{KB}$ signaling [384-386] and to A $\beta$ secretion [384], and they also demonstrate the profoundness of CDR1as deficiency in the brain [387].

\section{Conclusions}

The decrease of melatonin in aging and in various aging-related diseases [1,2] has different, potentially opposite, consequences. The same is valid for melatonin replacement therapies. This results from the dual roles of melatonin as both a pro- and anti-inflammatory regulator [15-17]. The conditionality that determines whether melatonin promotes the one or the other mode of immunological response should be a precondition for appropriately judging what kind of change has to be expected. Unfortunately, to date, this conditionality is not completely understood. Tendentially, one can conclude that anti-inflammatory actions of melatonin are mostly prevailing [17], however, with the important exception of autoimmune diseases, in which the immune stimulatory properties of melatonin may turn out to be detrimental. This concerns especially rheumatoid arthritis [50-52] and multiple sclerosis [53]. Whether melatonin may be unfavorable in type 2 diabetes of humans, in spite of its clearly antidiabetic actions in rodents, remains to be clarified in detail and may partially depend on age [5]. The difference between humans and rodents has to be seen in the contrasting associations of melatonin with food consumption and related metabolic activities in diurnality vs. nocturnality $[5,16]$. The inflammatory aspect of type 2 diabetes extends to brain insulin resistance, which has been identified as a proinflammatory change in early AD [107-109]. Whether or not melatonin may be detrimental in PD has been a matter of controversy [388-390]. The reported improvements by melatonergic antagonists in PD [390] should at least be regarded as a caveat [391].

Under other conditions, melatonin has been shown to preferentially exert anti-inflammatory, antioxidant, and other beneficial actions in aging [10,26,70,74,93-98,392-394]. Concerning anti-inflammatory effects, melatonin suppresses various processes that lead to enhanced formation of reactive oxygen and nitrogen species and to proinflammatory signaling, as summarized in Section 2. Moreover, it also stimulates several anti-inflammatory pathways and cellular changes that favor this side of the immune system and promote healing, as outlined in Section 3. Among these activities, the promotion of macrophage polarization towards the M2 type may be of particular importance for the shift from pro- to anti-inflammatory behavior, an aspect that has recently received increased attention [137,194,197]. Another potentially decisive action of melatonin concerns the upregulation of SIRT1 in nontumor cells, especially observed in aging animals [3,5,17,18,28,70,395]. Apart from being a relevant factor in aging, SIRT1 displays antioxidant and anti-inflammatory properties (Section 3). As mentioned above, various actions of melatonin are abolished by sirtuin inhibitors or Sirt1 siRNA. Moreover, some mitochondrial actions of melatonin were shown to be absent in Sirt1 ${ }^{-/-}$ mice [396]. The inclusion of SIRT1 and, perhaps, other sirtuins into the spectrum of melatonin's actions represents an important step forward in the understanding of its aging- and inflammation-related properties. However, one cannot expect that all SIRT1 actions mediate melatonergic regulation. SIRT1 is also controlled by various other factors, including accessory components of circadian oscillators that regulate NAMPT expression and NAD ${ }^{+}$levels, hormones such as triiodothyronine and glucocorticoids, oncogenes, lncRNAs such as HOTAIR, and various miRNAs not regulated by melatonin. The incoherence of melatonin effects on miRNAs and their targeting of typically otherwise 
melatonin-controlled transcription factors, such as Nrf2 and NF- $\mathrm{kB}$, is evident from Table 1. Moreover, several miRNAs up- or downregulated by melatonin do not cause a rise in SIRT1. However, in the latter case, one has to remain aware that melatonin downregulates SIRT1 in cancer cells, and that several of the miRNAs have been studied in tumors. The selection of miRNAs in Table 1 was restricted to those with demonstrated functions in the control of inflammation. More extensive studies on melatonin, SIRT1, and miRNAs will presumably reveal additional cases that are related to the immune system and also to aging and age-related diseases. As examples, the associated roles of SIRT1 and miRNAs in SASP and in A $\beta$ toxicity shall be briefly mentioned [125,397]. MicroRNAs and other noncoding RNAs have brought about a new, considerably expanded level of complexity into the relationships between melatonin, inflammation, and aging. There is considerable difficulty that arises from multiple mRNAs targeted by a single miRNA species. A further level of complexity in the regulatory networks can be expected as soon as the intercellular communication, via exosomal RNAs, is more profoundly understood in its details and its variations according to diseases and aging.

Conflicts of Interest: The author declares no conflict of interest.

\section{References}

1. Bubenik, G.A.; Konturek, S.J. Melatonin and aging: Prospects for human treatment. J. Physiol. Pharmacol. 2011, 62, 13-19. [PubMed]

2. Hardeland, R. Melatonin in aging and disease-Multiple consequences of reduced secretion, options and limits of treatment. Aging Dis. 2012, 3, 194-225. [PubMed]

3. Hardeland, R. Brain inflammaging: Roles of melatonin, circadian clocks and sirtuins. J. Clin. Cell. Immunol. 2018, 9, 543. [CrossRef]

4. Yamazaki, S.; Straume, M.; Tei, H.; Sakaki, Y.; Menaker, M.; Block, G.D. Effects of aging on central and peripheral mammalian clocks. Proc. Natl. Acad. Sci. USA 2002, 99, 10801-10806. [CrossRef] [PubMed]

5. Hardeland, R. Melatonin and the pathologies of weakened or dysregulated circadian oscillators. J. Pineal Res. 2017, 62, e12377. [CrossRef] [PubMed]

6. Ginaldi, L.; De Martinis, M.; D'Ostilio, A.; Marini, L.; Loreto, M.F.; Quaglino, D. Immunological changes in the elderly. Aging 1999, 11, 281-286. [CrossRef] [PubMed]

7. DelaRosa, O.; Pawelec, G.; Peralbo, E.; Wikby, A.; Mariani, E.; Mocchegiani, E.; Tarazona, R.; Solana, R. Immunological biomarkers of ageing in man: Changes in both innate and adaptive immunity are associated with health and longevity. Biogerontology 2006, 7, 471-481. [CrossRef] [PubMed]

8. Dewan, S.K.; Zheng, S.B.; Xia, S.J.; Bill, K. Senescent remodeling of the immune system and its contribution to the predisposition of the elderly to infections. Chin. Med. J. 2012, 125, 3325-3331. [PubMed]

9. Cardinali, D.P.; Esquifino, A.I.; Srinivasan, V.; Pandi-Perumal, S.R. Melatonin and the immune system in aging. Neuroimmunomodulation 2008, 15, 272-278. [CrossRef] [PubMed]

10. Hardeland, R. Melatonin and the theories of aging: A critical appraisal of melatonin's role in antiaging mechanisms. J. Pineal Res. 2013, 55, 325-356. [CrossRef] [PubMed]

11. Hardeland, R.; Cardinali, D.P.; Srinivasan, V.; Spence, D.W.; Brown, G.M.; Pandi-Perumal, S.R. Melatonin-A pleiotropic, orchestrating regulator molecule. Prog. Neurobiol. 2011, 93, 350-384. [CrossRef] [PubMed]

12. Gachon, F.; Nagoshi, E.; Brown, S.A.; Ripperger, J.; Schibler, U. The mammalian circadian timing system: From gene expression to physiology. Chromosoma 2004, 113, 103-112. [CrossRef] [PubMed]

13. Buijs, R.M.; Scheer, F.A.; Kreier, F.; Yi, C.; Bos, N.; Goncharuk, V.D.; Kalsbeek, A. Organization of circadian functions: Interaction with the body. Prog. Brain Res. 2006, 153, 341-360. [PubMed]

14. Hardeland, R. Melatonin and circadian oscillators in aging-A dynamic approach to the multiply connected players. Interdiscip. Top. Gerontol. 2015, 40, 128-140. [PubMed]

15. Carrillo-Vico, A.; Lardone, P.J.; Álvarez-Sánchez, N.; Rodríguez-Rodríguez, A.; Guerrero, J.M. Melatonin: Buffering the immune system. Int. J. Mol. Sci. 2013, 14, 8638-8683. [CrossRef] [PubMed]

16. Hardeland, R. Opposite effects of melatonin in different systems and under different conditions. Curr. Top. Biochem. Res. 2016, 17, 57-69. 
17. Hardeland, R. Melatonin and inflammation—Story of a double-edged blade. J. Pineal Res. 2018, 65, e12525. [CrossRef] [PubMed]

18. Hardeland, R. Melatonin and retinoid orphan receptors: Demand for new interpretations after their exclusion as nuclear melatonin receptors. Melatonin Res. 2018, 1, 77-92. [CrossRef]

19. Nakahata, Y.; Sahar, S.; Astarita, G.; Kaluzova, M.; Sassone-Corsi, P. Circadian control of the NAD ${ }^{+}$salvage pathway by CLOCK-SIRT1. Science 2009, 324, 654-657. [CrossRef] [PubMed]

20. Bellet, M.M.; Orozco-Solis, R.; Sahar, S.; Eckel-Mahan, K.; Sassone-Corsi, P. The time of metabolism: NAD ${ }^{+}$, SIRT1, and the circadian clock. Cold Spring Harb. Symp. Quant. Biol. 2011, 76, 31-38. [CrossRef] [PubMed]

21. Sahar, S.; Sassone-Corsi, P. The epigenetic language of circadian clocks. Handb. Exp. Pharmacol. 2013, 217, 29-44.

22. Masri, S. Sirtuin-dependent clock control: New advances in metabolism, aging and cancer. Curr. Opin. Clin. Nutr. Metab. Care 2015, 18, 521-527. [CrossRef] [PubMed]

23. Li, D.; Bi, F.F.; Chen, N.N.; Cao, J.M.; Sun, W.P.; Zhou, Y.M.; Li, C.Y.; Yang, Q. A novel crosstalk between BRCA1 and sirtuin 1 in ovarian cancer. Sci. Rep. 2014, 4, 6666. [CrossRef] [PubMed]

24. Ramsey, K.M.; Mills, K.F.; Satoh, A.; Imai, S. Age-associated loss of sirt1-mediated enhancement of glucose-stimulated insulin secretion in beta cell-specific sirt1-overexpressing (besto) mice. Aging Cell 2008, 7, 78-88. [CrossRef] [PubMed]

25. Elibol, B.; Kilic, U. High levels of SIRT1 expression as a protective mechanism against disease-related conditions. Front Endocrinol. 2018, 9, 614. [CrossRef] [PubMed]

26. Gutierrez-Cuesta, J.; Tajes, M.; Jiménez, A.; Coto-Montes, A.; Camins, A.; Pallàs, M. Evaluation of potential pro-survival pathways regulated by melatonin in a murine senescence model. J. Pineal Res. 2008, 45, 497-505. [CrossRef] [PubMed]

27. Tajes, M.; Gutierrez-Cuesta, J.; Ortuño-Sahagun, D.; Camins, A.; Pallàs, M. Anti-aging properties of melatonin in an in vitro murine senescence model: Involvement of the sirtuin 1 pathway. J. Pineal Res. 2009, 47, $228-237$. [CrossRef] [PubMed]

28. Cristòfol, R.; Porquet, D.; Corpas, R.; Coto-Montes, A.; Serret, J.; Camins, A.; Pallàs, M.; Sanfeliu, C. Neurons from senescence-accelerated SAMP8 mice are protected against frailty by the sirtuin 1 promoting agents melatonin and resveratrol. J. Pineal Res. 2012, 52, 271-281. [CrossRef] [PubMed]

29. Guo, P.; Pi, H.; Xu, S.; Zhang, L.; Li, Y.; Li, M.; Cao, Z.; Tian, L.; Xie, J.; Li, R.; et al. Melatonin Improves mitochondrial function by promoting MT1/SIRT1/PGC-1 alpha-dependent mitochondrial biogenesis in cadmium-induced hepatotoxicity in vitro. Toxicol. Sci. 2014, 142, 182-195. [CrossRef] [PubMed]

30. Yu, L.; Sun, Y.; Cheng, L.; Jin, Z.; Yang, Y.; Zhai, M.; Pei, H.; Wang, X.; Zhang, H.; Meng, Q.; et al. Melatonin receptor-mediated protection against myocardial ischemia/reperfusion injury: Role of SIRT1. J. Pineal Res. 2014, 57, 228-238. [CrossRef] [PubMed]

31. Yu, L.; Liang, H.; Dong, X.; Zhao, G.; Jin, Z.; Zhai, M.; Yang, Y.; Chen, W.; Liu, J.; Yi, W.; et al. Reduced silent information regulator 1 signaling exacerbates myocardial ischemia-reperfusion injury in type 2 diabetic rats and the protective effect of melatonin. J. Pineal Res. 2015, 59, 376-390. [CrossRef] [PubMed]

32. Zhao, L.; An, R.; Yang, Y.; Yang, X.; Liu, H.; Yue, L.; Li, X.; Lin, Y.; Reiter, R.J.; Qu, Y. Melatonin alleviates brain injury in mice subjected to cecal ligation and puncture via attenuating inflammation, apoptosis, and oxidative stress: The role of SIRT1 signaling. J. Pineal Res. 2015, 59, 230-239. [CrossRef] [PubMed]

33. Zhou, L.; Chen, X.; Liu, T.; Gong, Y.; Chen, S.; Pan, G.; Cui, W.; Luo, Z.P.; Pei, M.; Yang, H.; et al. Melatonin reverses $\mathrm{H}_{2} \mathrm{O}_{2}$-induced premature senescence in mesenchymal stem cells via the SIRT1-dependent pathway. J. Pineal Res. 2015, 59, 190-205. [CrossRef] [PubMed]

34. Yang, Y.; Jiang, S.; Dong, Y.; Fan, C.; Zhao, L.; Yang, X.; Li, J.; Di, S.; Yue, L.; Liang, G.; et al. Melatonin prevents cell death and mitochondrial dysfunction via a SIRT1-dependent mechanism during ischemic-stroke in mice. J. Pineal Res. 2015, 58, 61-70. [CrossRef] [PubMed]

35. Lee, J.H.; Moon, J.H.; Nazim, U.M.; Lee, Y.J.; Seol, J.W.; Eo, S.K.; Lee, J.H.; Park, S.Y. Melatonin protects skin keratinocyte from hydrogen peroxide-mediated cell death via the SIRT1 pathway. Oncotarget 2016, 7, 12075-12088. [CrossRef] [PubMed]

36. Bai, X.Z.; He, T.; Gao, J.X.; Liu, Y.; Liu, J.Q.; Han, S.C.; Li, Y.; Shi, J.H.; Han, J.T.; Tao, K.; et al. Melatonin prevents acute kidney injury in severely burned rats via the activation of SIRT1. Sci. Rep. 2016, 6, 32199. [CrossRef] [PubMed] 
37. Shah, S.A.; Khan, M.; Jo, M.H.; Jo, M.G.; Amin, F.U.; Kim, M.O. Melatonin stimulates the SIRT1/Nrf2 signaling pathway counteracting lipopolysaccharide (LPS)-induced oxidative stress to rescue postnatal rat brain. CNS Neurosci. Ther. 2017, 23, 33-44. [CrossRef] [PubMed]

38. Yang, W.; Kang, X.; Qin, N.; Li, F.; Jin, X.; Ma, Z.; Qian, Z.; Wu, S. Melatonin protects chondrocytes from impairment induced by glucocorticoids via NAD ${ }^{+}$-dependent SIRT1. Steroids 2017, 126, 24-29. [CrossRef] [PubMed]

39. Peng, Z.; Zhang, W.; Qiao, J.; He, B. Melatonin attenuates airway inflammation via SIRT1 dependent inhibition of NLRP3 inflammasome and IL-1 $\beta$ in rats with COPD. Int. Immunopharmacol. 2018, 62, 23-28. [CrossRef] [PubMed]

40. Hardeland, R.; Madrid, J.A.; Tan, D.X.; Reiter, R.J. Melatonin, the circadian multioscillator system and health: The need for detailed analyses of peripheral melatonin signaling. J. Pineal Res. 2012, 52, 139-166. [CrossRef] [PubMed]

41. Chang, H.C.; Guarente, L. SIRT1 mediates central circadian control in the SCN by a mechanism that decays with aging. Cell 2013, 153, 1448-1460. [CrossRef] [PubMed]

42. Hardeland, R. Extended signaling by melatonin. Cell Cell. Life Sci. J. 2018, 3, 000123.

43. Guerrero, J.M.; Reiter, R.J. Melatonin-immune system relationships. Curr. Top. Med. Chem. 2002, 2, 167-179. [CrossRef]

44. Carrillo-Vico, A.; Guerrero, J.M.; Lardone, P.J.; Reiter, R.J. A review of the multiple actions of melatonin on the immune system. Endocrine 2005, 27, 189-200. [CrossRef]

45. Carrillo-Vico, A.; Reiter, R.J.; Lardone, P.J.; Herrera, J.L.; Fernández-Montesinos, R.; Guerrero, J.M.; Pozo, D. The modulatory role of melatonin on immune responsiveness. Curr. Opin. Investig. Drugs 2006, 7, $423-431$. [PubMed]

46. Miller, S.C.; Pandi-Perumal, S.R.; Esquifino, A.I.; Cardinali, D.P.; Maestroni, G.J.M. The role of melatonin in immuno-enhancement: potential application in cancer. Int. J. Exp. Pathol. 2006, 87, 81-87. [CrossRef] [PubMed]

47. Pandi-Perumal, S.R.; Srinivasan, V.; Maestroni, G.J.M.; Cardinali, D.P.; Poeggeler, B.; Hardeland, R. Melatonin: Nature's most versatile biological signal? FEBS J. 2006, 273, 2813-2838. [CrossRef] [PubMed]

48. Carrillo-Vico, A.; Calvo, J.R.; Abreu, P.; Lardone, P.J.; García-Mauriño, S.; Reiter, R.J.; Guerrero, J.M. Evidence of melatonin synthesis by human lymphocytes and its physiological significance: Possible role as intracrine, autocrine, and/or paracrine substance. FASEB J. 2004, 18, 537-539. [CrossRef] [PubMed]

49. Carrillo-Vico, A.; Lardone, P.J.; Fernandez-Santos, J.M.; Martín-Lacave, I.; Calvo, J.R.; Karasek, M.; Guerrero, J.M. Human lymphocyte-synthesized melatonin is involved in the regulation of the interleukin-2/interleukin-2 receptor system. J. Clin. Endocrinol. MeTable 2005, 90, 992-1000. [CrossRef] [PubMed]

50. Maestroni, G.J.M.; Cardinali, D.P.; Esquifino, A.I.; Pandi-Perumal, S.R. Does melatonin play a disease-promoting role in rheumatoid arthritis? J. Neuroimmunol. 2005, 158, 106-111. [CrossRef] [PubMed]

51. Cutolo, M.; Maestroni, G.J.M. The melatonin-cytokine connection in rheumatoid arthritis. Ann. Rheum. Dis. 2005, 64, 1109-1111. [CrossRef] [PubMed]

52. Maestroni, G.J.M.; Otsa, K.; Cutolo, M. Melatonin treatment does not improve rheumatoid arthritis. Br. J. Clin. Pharmacol. 2008, 65, 797-798. [CrossRef] [PubMed]

53. Ghareghani, M.; Dokoohaki, S.; Ghanbari, A.; Farhadi, N.; Zibara, K.; Khodadoust, S.; Parishani, M.; Ghavamizadeh, M.; Sadeghi, H. Melatonin exacerbates acute experimental autoimmune encephalomyelitis by enhancing the serum levels of lactate: A potential biomarker of multiple sclerosis progression. Clin. Exp. Pharmacol. Physiol. 2017, 44, 52-61. [CrossRef] [PubMed]

54. Carrillo-Vico, A.; García-Mauriño, S.; Calvo, J.R.; Guerrero, J.M. Melatonin counteracts the inhibitory effect of PGE2 on IL-2 production in human lymphocytes via its mt1 membrane receptor. FASEB J. 2003, 17, 755-757. [CrossRef] [PubMed]

55. Morrey, K.M.; McLachlan, J.A.; Serkin, C.D.; Bakouche, O. Activation of human monocytes by the pineal hormone melatonin. J. Immunol. 1994, 153, 2671-2680. [PubMed]

56. Kuklina, E.M.; Glebezdina, N.S.; Nekrasova, I.V. Role of melatonin in the regulation of differentiation of T cells producing interleukin-17 (Th17). Bull. Exp. Biol. Med. 2016, 160, 656-658. [CrossRef] [PubMed] 
57. Jovanovic, D.V.; Di Battista, J.A.; Martel-Pelletier, J.; Jolicoeur, F.C.; He, Y.; Zhang, M.; Mineau, F.; Pelletier, J.P. IL-17 stimulates the production and expression of proinflammatory cytokines, IL-beta and TNF-alpha, by human macrophages. J. Immunol. 1998, 160, 3513-3521. [PubMed]

58. Shalom-Barak, T.; Quach, J.; Lotz, M. Interleukin-17-induced gene expression in articular chondrocytes is associated with activation of mitogen-activated protein kinases and NF-kB. J. Biol. Chem. 1998, 273, 27467-27473. [CrossRef] [PubMed]

59. Kawaguchi, M.; Kokubu, F.; Kuga, H.; Matsukura, S.; Hoshino, H.; Ieki, K.; Imai, T.; Adachi, M.; Huang, S.K. Modulation of bronchial epithelial cells by IL-17. J. Allergy Clin. Immunol. 2001, 108, 804-809. [CrossRef] [PubMed]

60. Molet, S.; Hamid, Q.; Davoine, F.; Nutku, E.; Taha, R.; Page, R.N.; Olivenstein, R.; Elias, J.; Chakir, J. IL-17 is increased in asthmatic airways and induces human bronchial fibroblasts to produce cytokines. J. Allergy Clin. Immunol. 2001, 108, 430-438. [CrossRef] [PubMed]

61. Paradowska, A.; Maślińiski, W.; Grzybowska-Kowalczyk, A.; Łacki, J. The function of interleukin 17 in the pathogenesis of rheumatoid arthritis. Arch. Immunol. Ther. Exp. 2007, 55, 329-334. [CrossRef]

62. Ishigame, H.; Kakuta, S.; Nagai, T.; Kadoki, M.; Nambu, A.; Komiyama, Y.; Fujikado, N.; Tanahashi, Y.; Akitsu, A.; Kotaki, H.; et al. Differential roles of interleukin-17A and -17F in host defense against mucoepithelial bacterial infection and allergic responses. Immunity 2009, 30, 108-119. [CrossRef] [PubMed]

63. Zhang, Y.; Huang, D.; Gao, W.; Yan, J.; Zhou, W.; Hou, X.; Liu, M.; Ren, C.; Wang, S.; Shen, J. Lack of IL-17 signaling decreases liver fibrosis in murine schistosomiasis japonica. Int. Immunol. 2015, 27, 317-325. [CrossRef] [PubMed]

64. Shabgah, A.G.; Fattahi, E.; Shahneh, F.Z. Interleukin-17 in human inflammatory diseases. Postepy Dermatol. Alergol. 2014, 31, 256-261. [CrossRef] [PubMed]

65. Yang, Z.Y.; Yuan, C.X. IL-17A promotes the neuroinflammation and cognitive function in sevoflurane anesthetized aged rats via activation of NF-kB signaling pathway. BMC Anesthesiol. 2018, 18, 147. [CrossRef] [PubMed]

66. Liu, F.; Ng, T.B.; Fung, M.C. Pineal indoles stimulate the gene expression of immunomodulating cytokines. J. Neural Transm. 2001, 108, 397-405. [CrossRef] [PubMed]

67. Maestroni, G.J.M. The immunoneuroendocrine role of melatonin. J. Pineal Res. 1993, 14, 1-10. [CrossRef] [PubMed]

68. Maestroni, G.J.M.; Hertens, E.; Galli, P.; Conti, A.; Pedrinis, E. Melatonin-induced T-helper cell hematopoietic cytokines resembling both interleukin-4 and dynorphin. J. Pineal Res. 1996, 21, 131-139. [CrossRef] [PubMed]

69. Maestroni, G.J.M. k-Opioid receptors in marrow stroma mediate the hematopoietic effects of melatonin-induced opioid cytokines. Ann. N. Y. Acad. Sci. 1998, 840, 411-419. [CrossRef] [PubMed]

70. Hardeland, R.; Cardinali, D.P.; Brown, G.M.; Pandi-Perumal, S.R. Melatonin and brain inflammaging. Prog. Neurobiol. 2015, 127-128, 46-63. [CrossRef] [PubMed]

71. Strindhall, J.; Nilsson, B.O.; Löfgren, S.; Ernerudh, J.; Pawelec, G.; Johansson, B.; Wikby, A. No Immune Risk Profile among individuals who reach 100 years of age: Findings from the Swedish NONA immune longitudinal study. Exp. Gerontol. 2007, 42, 753-761. [CrossRef] [PubMed]

72. Candore, G.; Caruso, C.; Colonna-Romano, G. Inflammation, genetic background and longevity. Biogerontology 2010, 11, 565-573. [CrossRef] [PubMed]

73. Ponnappan, S.; Ponnappan, U. Aging and immune function: Molecular mechanisms to interventions. Antioxid. Redox Signal. 2011, 14, 1551-1585. [CrossRef] [PubMed]

74. Hardeland, R.; Coto-Montes, A. New vistas on oxidative damage and aging. Open Biol. J. 2010, 3, 39-52. [CrossRef]

75. Hardeland, R. Melatonin and its metabolites as anti-nitrosating and anti-nitrating agents. J. Exp. Integr. Med. 2011, 1, 67-81. [CrossRef]

76. Hardeland, R. Neuroprotection by radical avoidance: Search for suitable agents. Molecules 2009, 14, 5054-5102. [CrossRef] [PubMed]

77. Hardeland, R. Melatonin and the electron transport chain. Cell. Mol. Life Sci. 2017, 74, 3883-3896. [CrossRef] [PubMed]

78. Reiter, R.J.; Rosales-Corral, S.; Tan, D.X.; Jou, M.J.; Galano, A.; Xu, B. Melatonin as a mitochondria-targeted antioxidant: One of evolution's best ideas. Cell. Mol. Life Sci. 2017, 74, 3863-3881. [CrossRef] [PubMed] 
79. Paradies, G.; Paradies, V.; Ruggiero, F.M.; Petrosillo, G. Mitochondrial bioenergetics decay in aging: Beneficial effect of melatonin. Cell. Mol. Life Sci. 2017, 74, 3897-3911. [CrossRef] [PubMed]

80. Slominski, A.T.; Zmijewski, M.A.; Semak, I.; Kim, T.K.; Janjetovic, Z.; Slominski, R.M.; Zmijewski, J.W. Melatonin, mitochondria, and the skin. Cell. Mol. Life Sci. 2017, 74, 3913-3925. [CrossRef] [PubMed]

81. Cardinali, D.P.; Vigo, D.E. Melatonin, mitochondria, and the metabolic syndrome. Cell. Mol. Life Sci. 2017, 74, 3941-3954. [CrossRef] [PubMed]

82. Acuña-Castroviejo, D.; Rahim, I.; Acuña-Fernández, C.; Fernández-Ortiz, M.; Solera-Marín, J.; Sayed, R.K.A.; Díaz-Casado, M.E.; Rusanova, I.; López, L.C.; Escames, G. Melatonin, clock genes and mitochondria in sepsis. Cell. Mol. Life Sci. 2017, 74, 3965-3987. [CrossRef] [PubMed]

83. Wongprayoon, P.; Govitrapong, P. Melatonin as a mitochondrial protector in neurodegenerative diseases. Cell. Mol. Life Sci. 2017, 74, 3999-4014. [CrossRef] [PubMed]

84. Tan, B.; Choi, R.H.; Chin, T.J.; Kaur, C.; Ling, E.A. Manipulation of microglial activity as a therapy for Alzheimer's disease. Front. Biosci. (Schol. Ed.) 2012, 4, 1402-1412. [PubMed]

85. McLarnon, J.G. Correlated inflammatory responses and neurodegeneration in peptide-injected animal models of Alzheimer's disease. Biomed. Res. Int. 2014, 2014, 923670. [CrossRef] [PubMed]

86. Narayan, P.; Holmström, K.M.; Kim, D.H.; Whitcomb, D.J.; Wilson, M.R.; St George-Hyslop, P.; Wood, N.W.; Dobson, C.M.; Cho, K.; Abramov, A.Y.; et al. Rare individual amyloid- $\beta$ oligomers act on astrocytes to initiate neuronal damage. Biochemistry 2014, 53, 2442-2453. [CrossRef] [PubMed]

87. Hanzel, C.E.; Pichet-Binette, A.; Pomentel, L.S.; Iulita, M.F.; Allard, S.; Ducatenzeiler, A.; Do Carmo, S.; Cuello, A.C. Neuronal driven pre-plaque inflammation in a transgenic rat model of Alzheimer's disease. Neurobiol. Aging 2014, 35, 2249-2262. [CrossRef] [PubMed]

88. Iliff, J.J.; Wang, M.; Liao, Y.; Plogg, B.A.; Peng, W.; Gundersen, G.A.; Benveniste, H.; Vates, G.E.; Deane, R.; Goldman, S.A.; et al. A paravascular pathway facilitates CSF flow through the brain parenchyma and the clearance of interstitial solutes, including amyloid $\beta$. Sci. Transl. Med. 2012, 4, 147ra111. [CrossRef] [PubMed]

89. Mendelsohn, A.R.; Larrick, J.W. Sleep facilitates clearance of metabolites from the brain: Glymphatic function in aging and neurodegenerative diseases. Rejuvenation Res. 2013, 16, 518-523. [CrossRef] [PubMed]

90. Plog, B.A.; Nedergaard, M. The glymphatic system in central nervous system health and disease: Past, present, and future. Annu. Rev. Pathol. 2018, 13, 379-394. [CrossRef] [PubMed]

91. Boespflug, E.L.; Iliff, J.J. The emerging relationship between interstitial fluid-cerebrospinal fluid exchange, amyloid- $\beta$, and sleep. Biol. Psychiatry 2018, 83, 328-336. [CrossRef] [PubMed]

92. Yulug, B.; Hanoglu, L.; Kilic, E. Does sleep disturbance affect the amyloid clearance mechanisms in Alzheimer's disease? Psychiatry Clin. Neurosci. 2017, 71, 673-677. [CrossRef] [PubMed]

93. Pappolla, M.A.; Matsubara, E.; Vidal, R.; Pacheco-Quinto, J.; Poeggeler, B.; Zagorski, M.; Sambamurti, K. Melatonin treatment enhances $A \beta$ lymphatic clearance in a transgenic mouse model of amyloidosis. Curr. Alzheimer Res. 2018, 15, 637-642. [CrossRef] [PubMed]

94. Spinedi, E.; Cardinali, D.P. Neuroendocrine-metabolic dysfunction and sleep disturbances in neurodegenerative disorders: Focus on Alzheimer's Disease and melatonin. Neuroendocrinology 2018. [CrossRef] [PubMed]

95. Pappolla, M.A.; Chyan, Y.; Poeggeler, B.; Frangione, B.; Wilson, G.; Ghiso, J.; Reiter, R.J. An assessment of the antioxidant and the antiamyloidogenic properties of melatonin: Implications for Alzheimer's disease. J. Neural Transm. 2000, 107, 203-231. [CrossRef] [PubMed]

96. Srinivasan, V.; Pandi-Perumal, S.R.; Cardinali, D.P.; Poeggeler, B.; Hardeland, R. Melatonin in Alzheimer's disease and other neurodegenerative disorders. Behav. Brain Funct. 2006, 2, 15. [CrossRef] [PubMed]

97. Rosales-Corral, S.A.; Acuña-Castroviejo, D.; Coto-Montes, A.; Boga, J.A.; Manchester, L.C.; Fuentes-Broto, L.; Korkmaz, A.; Ma, S.; Tan, D.X.; Reiter, R.J. Alzheimer's disease: Pathological mechanisms and the beneficial role of melatonin. J. Pineal Res. 2012, 52, 167-202. [CrossRef] [PubMed]

98. Lin, L.; Huang, Q.X.; Yang, S.S.; Chu, J.; Wang, J.Z.; Tian, Q. Melatonin in Alzheimer's disease. Int. J. Mol. Sci. 2013, 14, 14575-14593. [CrossRef] [PubMed]

99. Song, W.; Lahiri, D.K. Melatonin alters the metabolism of the $\beta$-amyloid precursor protein in the neuroendocrine cell line PC12. J. Mol. Neurosci. 1997, 9, 75-92. [CrossRef] [PubMed] 
100. Panmanee, J.; Nopparat, C.; Chavanich, N.; Shukla, M.; Mukda, S.; Song, W.; Vincent, B.; Govitrapong, P. Melatonin regulates the transcription of $\beta$ APP-cleaving secretases mediated through melatonin receptors in human neuroblastoma SH-SY5Y cells. J. Pineal Res. 2015, 58, 151-165. [CrossRef] [PubMed]

101. Shukla, M.; Htoo, H.H.; Wintachai, P.; Hernandez, J.F.; Dubois, C.; Postina, R.; Xu, H.; Checler, F.; Smith, D.R.; Govitrapong, P.; et al. Melatonin stimulates the nonamyloidogenic processing of $\beta$ APP through the positive transcriptional regulation of ADAM10 and ADAM17. J. Pineal Res. 2015, 58, 151-165. [CrossRef] [PubMed]

102. Mukda, S.; Panmanee, J.; Boontem, P.; Govitrapong, P. Melatonin administration reverses the alteration of amyloid precursor protein-cleaving secretases expression in aged mouse hippocampus. Neurosci. Lett. 2016, 621, 39-46. [CrossRef] [PubMed]

103. Shukla, M.; Govitrapong, P.; Boontem, P.; Reiter, R.J.; Satayavivad, J. Mechanisms of melatonin in alleviating Alzheimer's disease. Curr. Neuropharmacol. 2017, 15, 1010-1031. [CrossRef] [PubMed]

104. Matsubara, E.; Bryant-Thomas, T.; Pacheco Quinto, J.; Henry, T.L.; Poeggeler, B.; Herbert, D.; Cruz-Sanchez, F.; Chyan, Y.J.; Smith, M.A.; Perry, G.; et al. Melatonin increases survival and inhibits oxidative and amyloid pathology in a transgenic model of Alzheimer's disease. J. Neurochem. 2003, 85, 1101-1108. [CrossRef] [PubMed]

105. Olcese, J.M.; Cao, C.; Mori, T.; Mamcarz, M.B.; Maxwell, A.; Runfeldt, M.J.; Wang, L.; Zhang, C.; Lin, X.; Zhang, G.; et al. Protection against cognitive deficits and markers of neurodegeneration by long-term oral administrations of melatonin in a transgenic model of Alzheimer disease. J. Pineal Res. 2009, 47, 82-96. [CrossRef] [PubMed]

106. Quinn, J.; Kulhanek, D.; Nowlin, J.; Jones, R.; Praticò, D.; Rokach, J.; Stackman, R. Chronic melatonin therapy fails to alter amyloid burden or oxidative damage in old Tg2576 mice: Implications for clinical trials. Brain Res. 2005, 1037, 209-213. [CrossRef] [PubMed]

107. Clark, I.A.; Vissel, B. Treatment implications of the altered cytokine-insulin axis in neurodegenerative disease. Biochem. Pharmacol. 2013, 86, 862-871. [CrossRef] [PubMed]

108. Jiang, T.; Yu, J.T.; Zhu, X.C.; Tan, L. TREM2 in Alzheimer's disease. Mol. Neurobiol. 2013, 48, $180-185$. [CrossRef] [PubMed]

109. Ferreira, L.S.S.; Fernandes, C.S.; Vieira, M.N.N.; De Felice, F.G. Insulin resistance in Alzheimer's disease. Front. Neurosci. 2018, 12, 830. [CrossRef] [PubMed]

110. Hotamisligil, G.S.; Erbay, E. Nutrient sensing and inflammation in metabolic diseases. Nat. Rev. Immunol. 2008, 8, 923-934. [CrossRef] [PubMed]

111. Hotamisligil, G.S. Inflammation, metaflammation and immunometabolic disorders. Nature 2017, 542, 177-185. [CrossRef] [PubMed]

112. Franceschi, C.; Garagnani, P.; Parini, P.; Giuliani, C.; Santoro, A. Inflammaging: A new immune-metabolic viewpoint for age-related diseases. Nat. Rev. Endocrinol. 2018, 14, 576-590. [CrossRef] [PubMed]

113. Cardinali, D.P.; Hardeland, R. Inflammaging, metabolic syndrome and melatonin: A call for treatment studies. Neuroendocrinology 2017, 104, 382-397. [CrossRef] [PubMed]

114. Coppé, J.P.; Patil, C.K.; Rodier, F.; Sun, Y.; Muñoz, D.P.; Goldstein, J.; Nelson, P.S.; Desprez, P.Y.; Campisi, J. Senescence-associated secretory phenotypes reveal cell-nonautonomous functions of oncogenic RAS and p53 tumor suppressor. PLoS Biol. 2008, 6, 2853-2868. [CrossRef] [PubMed]

115. Young, A.R.J.; Narita, M. SASP reflects senescence. EMBO Rep. 2009, 10, 228-230. [CrossRef] [PubMed]

116. Fumagalli, M.; d'Adda di Fagagna, F. SASPense and DDRama in cancer and ageing. Nat. Cell Biol. 2009, 11, 921-923. [CrossRef] [PubMed]

117. Coppé, J.P.; Desprez, P.Y.; Krtolica, A.; Campisi, J. The senescence-associated secretory phenotype: The dark side of tumor suppression. Annu. Rev. Pathol. 2010, 5, 99-118. [CrossRef] [PubMed]

118. Pantsulaia, I.; Ciszewski, W.M.; Niewiarowska, J. Senescent endothelial cells: Potential modulators of immunosenescence and ageing. Ageing Res. Rev. 2016, 29, 13-25. [CrossRef] [PubMed]

119. Salminen, A.; Ojala, J.; Kaamiranta, K.; Haapasalo, A.; Hiltunen, M.; Soininen, H. Astrocytes in the aging brain express characteristics of senescence-associated secretory phenotype. Eur. J. Neurosci. 2011, 34, 3-11. [CrossRef] [PubMed]

120. Maciel-Barón, L.Á.; Morales-Rosales, S.L.; Silva-Palacios, A.; Rodríguez-Barrera, R.H.; García-Álvarez, J.A.; Luna-López, A.; Pérez, V.I.; Torres, C.; Königsberg, M. The secretory phenotype of senescent astrocytes isolated from Wistar newborn rats changes with anti-inflammatory drugs, but does not have a short-term effect on neuronal mitochondrial potential. Biogerontology 2018, 19, 415-433. [CrossRef] [PubMed] 
121. Carroll, J.E.; Cole, S.W.; Seeman, T.E.; Breen, E.C.; Witarama, T.; Arevalo, J.M.; Ma, J.; Irwin, M.R. Partial sleep deprivation activates the DNA damage response (DDR) and the senescence-associated secretory phenotype (SASP) in aged adult humans. Brain Behav. Immun. 2016, 51, 223-229. [CrossRef] [PubMed]

122. Yu, S.; Wang, X.; Geng, P.; Tang, X.; Xiang, L.; Lu, X.; Li, J.; Ruan, Z.; Chen, J.; Xie, G.; et al. Melatonin regulates PARP1 to control the senescence-associated secretory phenotype (SASP) in human fetal lung fibroblast cells. J. Pineal Res. 2017, 63, e12405. [CrossRef] [PubMed]

123. Bae, W.J.; Park, J.S.; Kang, S.K.; Kwon, I.K.; Kim, E.C. Effects of melatonin and its underlying mechanism on ethanol-stimulated senescence and osteoclastic differentiation in human periodontal ligament cells and cementoblasts. Int. J. Mol. Sci. 2018, 19, 1742. [CrossRef] [PubMed]

124. Fang, J.; Yan, Y.; Teng, X.; Wen, X.; Li, N.; Peng, S.; Liu, W.; Donadeu, F.X.; Zhao, S.; Hua, J. Melatonin prevents senescence of canine adipose-derived mesenchymal stem cells through activating NRF2 and inhibiting ER stress. Aging 2018, 10, 2954-2972. [CrossRef] [PubMed]

125. Hekmatimoghaddam, S.; Dehghani Firoozabadi, A.; Zare-Khormizi, M.R.; Pourrajab, F. Sirt1 and Parp1 as epigenome safeguards and microRNAs as SASP-associated signals, in cellular senescence and aging. Ageing Res. Rev. 2017, 40, 120-141. [CrossRef] [PubMed]

126. Korkmaz, A.; Rosales-Corral, S.; Reiter, R.J. Gene regulation by melatonin linked to epigenetic phenomena. Gene 2012, 503, 1-11. [CrossRef] [PubMed]

127. Franceschi, C.; Garagnani, P.; Vitale, G.; Capri, M.; Salvioli, S. Inflammaging and 'garb-aging'. Trends Endocrinol. MeTable 2017, 28, 199-212. [CrossRef] [PubMed]

128. Gilthorpe, J.D.; Oozeer, F.; Nash, J.; Calvo, M.; Bennett, D.L.; Lumsden, A.; Pini, A. Extracellular histone H1 is neurotoxic and drives a pro-inflammatory response in microglia. F1000Resarch 2013, 2, 148. [CrossRef] [PubMed]

129. Shimada, K.; Crother, T.R.; Karlin, J.; Dagvadorj, J.; Chiba, N.; Chen, S.; Ramanujan, V.K.; Wolf, A.J.; Vergnes, L.; Ojcius, D.M.; et al. Oxidized mitochondrial DNA activates the NLRP3 inflammasome during apoptosis. Immunity 2012, 36, 401-414. [CrossRef] [PubMed]

130. Fang, C.; Wei, X.; Wei, Y. Mitochondrial DNA in the regulation of innate immune responses. Protein Cell 2016, 7, 11-16. [CrossRef] [PubMed]

131. Glück, S.; Ablasser, A. Innate immunosensing of DNA in cellular senescence. Curr. Opin. Immunol. 2018, 56, 31-36. [CrossRef] [PubMed]

132. Rongvaux, A. Innate immunity and tolerance toward mitochondria. Mitochondrion 2018, 41, 14-20. [CrossRef] [PubMed]

133. Escames, G.; López, L.C.; García, J.A.; García-Corzo, L.; Ortiz, F.; Acuña-Castroviejo, D. Mitochondrial DNA and inflammatory diseases. Hum. Genet. 2012, 131, 161-173. [CrossRef] [PubMed]

134. Rahim, I.; Djerdjouri, B.; Sayed, R.K.; Fernández-Ortiz, M.; Fernández-Gil, B.; Hidalgo-Gutiérrez, A.; López, L.C.; Escames, G.; Reiter, R.J.; Acuña-Castroviejo, D. Melatonin administration to wild-type mice and nontreated NLRP3 mutant mice share similar inhibition of the inflammatory response during sepsis. J. Pineal Res. 2017, 63, e12410. [CrossRef] [PubMed]

135. Glück, S.; Guey, B.; Gulen, M.F.; Wolter, K.; Kang, T.W.; Schmacke, N.A.; Bridgeman, A.; Rehwinkel, J.; Zender, L.; Ablasser, A. Innate immune sensing of cytosolic chromatin fragments through cGAS promotes senescence. Nat. Cell Biol. 2017, 19, 1061-1070. [CrossRef] [PubMed]

136. Hamann, L.; Ruiz-Moreno, J.S.; Szwed, M.; Mossakowska, M.; Lundvall, L.; Schumann, R.R.; Opitz, B.; Puzianowska-Kuznicka, M. STING SNP R293Q is associated with a decreased risk of aging-related diseases. Gerontology 2018, 26, 1-10. [CrossRef] [PubMed]

137. Liu, Z.; Gan, L.; Xu, Y.; Luo, D.; Ren, Q.; Wu, S.; Sun, C. Melatonin alleviates inflammasome-induced pyroptosis through inhibiting NF-kB/GSDMD signal in mice adipose tissue. J. Pineal Res. 2017, 63, e12414. [CrossRef] [PubMed]

138. Deng, W.G.; Tang, S.T.; Tseng, H.P.; Wu, K.K. Melatonin suppresses macrophage cyclooxygenase-2 and inducible nitric oxide synthase expression by inhibiting p52 acetylation and binding. Blood 2006, 108, 518-524. [CrossRef] [PubMed]

139. Negi, G.; Kumar, A.; Sharma, S.S. Melatonin modulates neuroinflammation and oxidative stress in experimental diabetic neuropathy: Effects on NF-kB and Nrf2 cascades. J. Pineal Res. 2011, 50, 124-131. [CrossRef] [PubMed] 
140. Murakami, Y.; Yuhara, K.; Takada, N.; Arai, T.; Tsuda, S.; Takamatsu, S.; Machino, M.; Fujisawa, S. Effect of melatonin on cyclooxygenase-2 expression and nuclear factor-kappa B activation in RAW264. 7 macrophage-like cells stimulated with fimbriae of Porphyromonas gingivalis. In Vivo 2011, 25, 641-647. [PubMed]

141. Shi, D.; Xiao, X.; Wang, J.; Liu, L.; Chen, W.; Fu, L.; Xie, F.; Huang, W.; Deng, W. Melatonin suppresses proinflammatory mediators in lipopolysaccharide-stimulated CRL1999 cells via targeting MAPK, NF- $k B$, c/EBP $\beta$, and p300 signaling. J. Pineal Res. 2012, 53, 154-165. [CrossRef] [PubMed]

142. Chinchalongporn, V.; Shukla, M.; Govitrapong, P. Melatonin ameliorates A $\beta 42$-induced alteration of

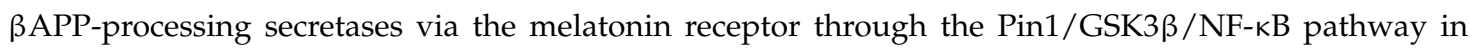
SH-SY5Y cells. J. Pineal Res. 2018, 64, e12470. [CrossRef] [PubMed]

143. Xia, M.Z.; Liang, Y.L.; Wang, H.; Chen, X.; Huang, Y.Y.; Zhang, Z.H.; Chen, Y.H.; Zhang, C.; Zhao, M.; Xu, D.X.; et al. Melatonin modulates TLR4-mediated inflammatory genes through MyD88- and TRIF-dependent signaling pathways in lipopolysaccharide-stimulated RAW264.7 cells. J. Pineal Res. 2012, 53, 325-334. [CrossRef] [PubMed]

144. Chuffa, L.G.; Fioruci-Fontanelli, B.A.; Mendes, L.O.; Ferreira Seiva, F.R.; Martinez, M.; Fávaro, W.J.; Domeniconi, R.F.; Pinheiro, P.F.; Delazari Dos Santos, L.; Martinez, F.E. Melatonin attenuates the TLR4-mediated inflammatory response through MyD88- and TRIF-dependent signaling pathways in an in vivo model of ovarian cancer. BMC Cancer 2015, 15, 34. [CrossRef] [PubMed]

145. Kang, J.W.; Koh, E.J.; Lee, S.M. Melatonin protects liver against ischemia and reperfusion injury through inhibition of toll-like receptor signaling pathway. J. Pineal Res. 2011, 50, 403-411. [CrossRef] [PubMed]

146. Huang, S.H.; Cao, X.J.; Wei, W. Melatonin decreases TLR3-mediated inflammatory factor expression via inhibition of NF- $\mathrm{BB}$ activation in respiratory syncytial virus-infected RAW264.7 macrophages. J. Pineal Res. 2008, 45, 93-100. [CrossRef] [PubMed]

147. Ding, K.; Wang, H.; Xu, J.; Lu, X.; Zhang, L.; Zhu, L. Melatonin reduced microglial activation and alleviated neuroinflammation induced neuron degeneration in experimental traumatic brain injury: Possible involvement of mTOR pathway. Neurochem. Int. 2014, 76, 23-31. [CrossRef] [PubMed]

148. Jumnongprakhon, P.; Govitrapong, P.; Tocharus, C.; Pinkaew, D.; Tocharus, J. Melatonin protects methamphetamine-induced neuroinflammation through NF- $\mathrm{BB}$ and Nrf2 pathways in glioma cell line. Neurochem. Res. 2015, 40, 1448-1456. [CrossRef] [PubMed]

149. Ismail, I.A.; El-Bakry, H.A.; Soliman, S.S. Melatonin and tumeric ameliorate aging-induced changes: Implication of immunoglobulins, cytokines, DJ-1/NRF2 and apoptosis regulation. Int. J. Physiol. Pathophysiol. Pharmacol. 2018, 10, 70-82. [PubMed]

150. El-Bakry, H.A.; Ismail, I.A.; Soliman, S.S. Immunosenescence-like state is accelerated by constant light exposure and counteracted by melatonin or turmeric administration through DJ-1/Nrf2 and P53/Bax pathways. J. Photochem. Photobiol. B 2018, 186, 69-80. [CrossRef] [PubMed]

151. Wang, J.; Jiang, C.; Zhang, K.; Lan, X.; Chen, X.; Zang, W.; Wang, Z.; Guan, F.; Zhu, C.; Yang, X.; et al. Melatonin receptor activation provides cerebral protection after traumatic brain injury by mitigating oxidative stress and inflammation via the Nrf2 signaling pathway. Free Radic. Biol. Med. 2019, 131, 345-355. [CrossRef] [PubMed]

152. Ariga, H.; Takahashi-Niki, K.; Kato, I.; Maita, H.; Niki, T.; Iguchi-Ariga, S.M. Neuroprotective function of DJ-1 in Parkinson's disease. Oxid. Med. Cell. Longev. 2013, 2013, 683920. [CrossRef] [PubMed]

153. Poulose, N.; Raju, R. Sirtuin regulation in aging and injury. Biochim. Biophys. Acta 2015, 1852, $2442-2455$. [CrossRef] [PubMed]

154. Zhang, W.; Huang, Q.; Zeng, Z.; Wu, J.; Zhang, Y.; Chen, Z. Sirt1 inhibits oxidative stress in vascular endothelial cells. Oxid. Med. Cell. Longev. 2017, 2017, 7543973. [CrossRef] [PubMed]

155. Karbasforooshan, H.; Karimi, G. The role of SIRT1 in diabetic cardiomyopathy. Biomed. Pharmacother. 2017, 90, 386-392. [CrossRef] [PubMed]

156. Mendes, K.L.; Lelis, D.F.; Santos, S.H.S. Nuclear sirtuins and inflammatory signaling pathways. Cytokine Growth Factor Rev. 2017, 38, 98-105. [CrossRef] [PubMed]

157. Chai, D.; Zhang, L.; Xi, S.; Cheng, Y.; Jiang, H.; Hu, R. Nrf2 activation induced by Sirt1 ameliorates acute lung injury after intestinal ischemia/reperfusion through NOX4-mediated gene regulation. Cell. Physiol. Biochem. 2018, 46, 781-792. [CrossRef] [PubMed] 
158. Han, J.; Liu, X.; Li, Y.; Zhang, J.; Yu, H. Sirt1/Nrf2 signalling pathway prevents cognitive impairment in diabetic rats through anti-oxidative stress induced by miRNA-23b-3p expression. Mol. Med. Rep. 2018, 17, 8414-8422. [CrossRef] [PubMed]

159. Huang, K.; Li, R.; Wei, W. Sirt1 activation prevents anti-Thy 1.1 mesangial proliferative glomerulonephritis in the rat through the Nrf2/ARE pathway. Eur. J. Pharmacol. 2018, 832, 138-144. [CrossRef] [PubMed]

160. Yang, B.; Xu, B.; Zhao, H.; Wang, Y.B.; Zhang, J.; Li, C.W.; Wu, Q.; Cao, Y.K.; Li, Y.; Cao, F. Dioscin protects against coronary heart disease by reducing oxidative stress and inflammation via Sirt1/Nrf2 and p38 MAPK pathways. Mol. Med. Rep. 2018, 18, 973-980. [CrossRef] [PubMed]

161. Wang, X.; Yuan, B.; Cheng, B.; Liu, Y.; Zhang, B.; Wang, X.; Lin, X.; Yang, B.; Gong, G. Crocin alleviates myocardial ischemia/reperfusion-induced endoplasmic reticulum stress via regulation of miR-34a/Sirt1/Nrf2 pathway. Shock 2019, 51, 123-130. [CrossRef] [PubMed]

162. Li, Y.; Yang, G.; Yang, X.; Wang, W.; Zhang, J.; He, Y.; Zhang, W.; Jing, T.; Lin, R. Nicotinic acid inhibits NLRP3 inflammasome activation via SIRT1 in vascular endothelial cells. Int. Immunopharmacol. 2016, 40, 211-218. [CrossRef] [PubMed]

163. Li, Y.; Yang, X.; He, Y.; Wang, W.; Zhang, J.; Zhang, W.; Jing, T.; Wang, B.; Lin, R. Negative regulation of NLRP3 inflammasome by SIRT1 in vascular endothelial cells. Immunobiology 2017, 222, 552-561. [CrossRef] [PubMed]

164. Zhang, S.; Jiang, L.; Che, F.; Lu, Y.; Xie, Z.; Wang, H. Arctigenin attenuates ischemic stroke via SIRT1-dependent inhibition of NLRP3 inflammasome. Biochem. Biophys. Res. Commun. 2017, 493, 821-826. [CrossRef] [PubMed]

165. Zou, P.; Liu, X.; Li, G.; Wang, Y. Resveratrol pretreatment attenuates traumatic brain injury in rats by suppressing NLRP3 inflammasome activation via SIRT1. Mol. Med. Rep. 2018, 17, 3212-3217. [CrossRef] [PubMed]

166. Lin, Q.Q.; Geng, Y.W.; Jiang, Z.W.; Tian, Z.J. SIRT1 regulates lipopolysaccharide-induced CD40 expression in renal medullary collecting duct cells by suppressing the TLR4-NF-кB signaling pathway. Life Sci. 2017, 170, 100-107. [CrossRef] [PubMed]

167. Yuan, Y.; Liu, Q.; Zhao, J.; Tang, H.; Sun, J. SIRT1 attenuates murine allergic rhinitis by downregulated HMGB 1/TLR4 pathway. Scand. J. Immunol. 2018, 87, e12667. [CrossRef] [PubMed]

168. Li, K.; Lv, G.; Pan, L. Sirt1 alleviates LPS induced inflammation of periodontal ligament fibroblasts via downregulation of TLR4. Int. J. Biol. Macromol. 2018, 119, 249-254. [CrossRef] [PubMed]

169. Rabadi, M.M.; Xavier, S.; Vasko, R.; Kaur, K.; Goligorksy, M.S.; Ratliff, B.B. High-mobility group box 1 is a novel deacetylation target of Sirtuin1. Kidney Int. 2015, 87, 95-108. [CrossRef] [PubMed]

170. Hwang, J.S.; Choi, H.S.; Ham, S.A.; Yoo, T.; Lee, W.J.; Paek, K.S.; Seo, H.G. Deacetylation-mediated interaction of SIRT1-HMGB1 improves survival in a mouse model of endotoxemia. Sci. Rep. 2015, 5, 15971. [CrossRef] [PubMed]

171. Rickenbacher, A.; Jang, J.H.; Limani, P.; Ungethüm, U.; Lehmann, K.; Oberkofler, C.E.; Weber, A.; Graf, R.; Humar, B.; Clavien, P.A. Fasting protects liver from ischemic injury through Sirt1-mediated downregulation of circulating HMGB1 in mice. J. Hepatol. 2014, 61, 301-308. [CrossRef] [PubMed]

172. Xu, W.; Lu, Y.; Yao, J.; Li, Z.; Chen, Z.; Wang, G.; Jing, H.; Zhang, X.; Li, M.; Peng, J.; Tian, X. Novel role of resveratrol: Suppression of high-mobility group protein box 1 nucleocytoplasmic translocation by the upregulation of sirtuin 1 in sepsis-induced liver injury. Shock 2014, 42, 440-447. [CrossRef] [PubMed]

173. Hwang, J.S.; Lee, W.J.; Kang, E.S.; Ham, S.A.; Yoo, T.; Paek, K.S.; Lim, D.S.; Do, J.T.; Seo, H.G. Ligand-activated peroxisome proliferator-activated receptor- $\delta$ and $-\gamma$ inhibit lipopolysaccharide-primed release of high mobility group box 1 through upregulation of SIRT1. Cell Death Dis. 2014, 5, e1432. [CrossRef] [PubMed]

174. Yin, Y.; Feng, Y.; Zhao, H.; Zhao, Z.; Yua, H.; Xu, J.; Che, H. SIRT1 inhibits releases of HMGB1 and HSP70 from human umbilical vein endothelial cells caused by IL- 6 and the serum from a preeclampsia patient and protects the cells from death. Biomed. Pharmacother. 2017, 88, 449-458. [CrossRef] [PubMed]

175. Chen, X.; Wu, S.; Chen, C.; Wu, S.; Yang, F.; Fang, Z.; Fu, H.; Li, Y. Omega-3 polyunsaturated fatty acid supplementation attenuates microglial-induced inflammation by inhibiting the HMGB1/TLR4/NF- $\mathrm{kB}$ pathway following experimental traumatic brain injury. J. Neuroinflamm. 2017, 14, 143. [CrossRef] [PubMed]

176. Hwang, J.S.; Kang, E.S.; Han, S.G.; Lim, D.S.; Paek, K.S.; Lee, C.H.; Seo, H.G. Formononetin inhibits lipopolysaccharide-induced release of high mobility group box 1 by upregulating SIRT1 in a PPAR $\delta$-dependent manner. Peer J. 2018, 6, e4208. [CrossRef] [PubMed] 
177. Su, Z.; Zhang, P.; Yu, Y.; Lu, H.; Liu, Y.; Ni, P.; Su, X.; Wang, D.; Liu, Y.; Wang, J.; et al. HMGB1 facilitated macrophage reprogramming towards a proinflammatory M1-like phenotype in experimental autoimmune myocarditis development. Sci. Rep. 2016, 6, 21884. [CrossRef] [PubMed]

178. Karuppagounder, V.; Giridharan, V.V.; Arumugam, S.; Sreedhar, R.; Palaniyandi, S.S.; Krishnamurthy, P.; Quevedo, J.; Watanabe, K.; Konishi, T.; Thandavarayan, R.A. Modulation of macrophage polarization and HMGB1-TLR2/TLR4 cascade plays a crucial role for cardiac remodeling in senescence-accelerated prone mice. PLoS ONE 2016, 11, e0152922. [CrossRef] [PubMed]

179. Son, M.; Porat, A.; He, M.; Suurmond, J.; Santiago-Schwarz, F.; Andersson, U.; Coleman, T.R.; Volpe, B.T.; Tracey, K.J.; Al-Abed, Y.; et al. C1q and HMGB1 reciprocally regulate human macrophage polarization. Blood 2016, 128, 2218-2228. [CrossRef] [PubMed]

180. Jiang, Y.; Chen, R.; Shao, X.; Ji, X.; Lu, H.; Zhou, S.; Zong, G.; Xu, H.; Su, Z. HMGB1 silencing in macrophages prevented their functional skewing and ameliorated EAM development: Nuclear HMGB1 may be a checkpoint molecule of macrophage reprogramming. Int. Immunopharmacol. 2018, 56, 277-284. [CrossRef] [PubMed]

181. Gao, T.; Chen, Z.; Chen, H.; Yuan, H.; Wang, Y.; Peng, X.; Wei, C.; Yang, J.; Xu, C. Inhibition of HMGB1 mediates neuroprotection of traumatic brain injury by modulating the microglia/macrophage polarization. Biochem. Biophys. Res. Commun. 2018, 497, 430-436. [CrossRef] [PubMed]

182. Prieto-Domínguez, N.; Méndez-Blanco, C.; Carbajo-Pescador, S.; Fondevila, F.; García-Palomo, A.; González-Gallego, J.; Mauriz, J.L. Melatonin enhances sorafenib actions in human hepatocarcinoma cells by inhibiting mTORC1/p70S6K/HIF-1 $\alpha$ and hypoxia-mediated mitophagy. Oncotarget 2017, 8, 91402-91414. [CrossRef] [PubMed]

183. Fan, T.; Pi, H.; Li, M.; Ren, Z.; He, Z.; Zhu, F.; Tian, L.; Tu, M.; Xie, J.; Liu, M.; et al. Inhibiting MT2-TFE3-dependent autophagy enhances melatonin-induced apoptosis in tongue squamous cell carcinoma. J. Pineal Res. 2018, 64, e12457. [CrossRef] [PubMed]

184. Yun, S.M.; Woo, S.H.; Oh, S.T.; Hong, S.E.; Choe, T.B.; Ye, S.K.; Kim, E.K.; Seong, M.K.; Kim, H.A.; Noh, W.C.; et al. Melatonin enhances arsenic trioxide-induced cell death via sustained upregulation of Redd1 expression in breast cancer cells. Mol. Cell. Endocrinol. 2016, 422, 64-73. [CrossRef] [PubMed]

185. Liu, Z.; Gan, L.; Liu, G.; Chen, Y.; Wu, T.; Feng, F.; Sun, C. Sirt1 decreased adipose inflammation by interacting with Akt2 and inhibiting mTOR/S6K1 pathway in mice. J. Lipid Res. 2016, 57, 1373-1381. [CrossRef] [PubMed]

186. Chen, H.; Shen, F.; Sherban, A.; Nocon, A.; Li, Y.; Wang, H.; Xu, M.J.; Rui, X.; Han, J.; Jiang, B.; et al. DEP domain-containing mTOR-interacting protein suppresses lipogenesis and ameliorates hepatic steatosis and acute-on-chronic liver injury in alcoholic liver disease. Hepatology 2018, 68, 496-514. [CrossRef] [PubMed]

187. Guarani, V.; Deflorian, G.; Franco, C.A.; Krüger, M.; Phng, L.K.; Bentley, K.; Toussaint, L.; Dequiedt, F.; Mostoslavsky, R.; Schmidt, M.H.H.; et al. Acetylation-dependent regulation of endothelial Notch signalling by the SIRT1 deacetylase. Nature 2011, 473, 234-238. [CrossRef] [PubMed]

188. Bai, X.; He, T.; Liu, Y.; Li, X.; Shi, J.; Wang, K.; Han, F.; Zhang, W.; Zhang, Y.; Cai, W.; et al. Acetylation-dependent regulation of Notch signaling in macrophages by SIRT1 affects sepsis development. Front. Immunol. 2018, 9, 762. [CrossRef] [PubMed]

189. Yang, J.J.; Tao, H.; Liu, L.P.; Hu, W.; Deng, Z.Y.; Li, J. miR-200a controls hepatic stellate cell activation and fibrosis via SIRT1/Notch1 signal pathway. Inflamm. Res. 2017, 66, 341-352. [CrossRef] [PubMed]

190. Yu, L.; Liang, H.; Lu, Z.; Zhao, G.; Zhai, M.; Yang, Y.; Yang, J.; Yi, D.; Chen, W.; Wang, X.; et al. Membrane receptor-dependent Notch1/Hes1 activation by melatonin protects against myocardial ischemia-reperfusion injury: In vivo and in vitro studies. J. Pineal Res. 2015, 59, 420-433. [CrossRef] [PubMed]

191. Zhang, S.; Wang, P.; Ren, L.; Hu, C.; Bi, J. Protective effect of melatonin on soluble A $\beta_{1-42}$-induced memory impairment, astrogliosis, and synaptic dysfunction via the Musashi1/Notch1/Hes1 signaling pathway in the rat hippocampus. Alzheimers Res. Ther. 2016, 8, 40. [CrossRef] [PubMed]

192. Yu, L.; Fan, C.; Li, Z.; Zhang, J.; Xue, X.; Xu, Y.; Zhao, G.; Yang, Y.; Wang, H. Melatonin rescues cardiac thioredoxin system during ischemia-reperfusion injury in acute hyperglycemic state by restoring Notch1/Hes1/Akt signaling in a membrane receptor-dependent manner. J. Pineal Res. 2017, 62, e12375. [CrossRef] [PubMed] 
193. Jia, Y.; Li, Z.; Cai, W.; Xiao, D.; Han, S.; Han, F.; Bai, X.; Wang, K.; Liu, Y.; Li, X.; et al. SIRT1 regulates inflammation response of macrophages in sepsis mediated by long noncoding RNA. Biochim. Biophys. Acta 2018, 1864, 784-792. [CrossRef] [PubMed]

194. Xia, Y.; Chen, S.; Zeng, S.; Zhao, Y.; Zhu, C.; Deng, B.; Zhu, G.; Yin, Y.; Wang, W.; Hardeland, R.; et al. Melatonin in macrophage biology: Current understanding and future perspectives. J. Pineal Res. 2018, 66, e12547. [CrossRef] [PubMed]

195. Lau, W.W.; Ng, J.K.; Lee, M.M.; Chan, A.S.; Wong, Y.H. Interleukin-6 autocrine signaling mediates melatonin $\mathrm{MT}_{1 / 2}$ receptor-induced STAT3 $\mathrm{Tyr}_{705}$ phosphorylation. J. Pineal Res. 2012, 52, 477-489. [CrossRef] [PubMed]

196. Yang, Y.; Duan, W.; Jin, Z.; Yi, W.; Yan, J.; Zhang, S.; Wang, N.; Liang, Z.; Li, Y.; Chen, W.; et al. JAK2/STAT3 activation by melatonin attenuates the mitochondrial oxidative damage induced by myocardial ischemia/reperfusion injury. J. Pineal Res. 2013, 55, 275-286. [CrossRef] [PubMed]

197. Yi, W.J.; Kim, T.S. Melatonin protects mice against stress-induced inflammation through enhancement of M2 macrophage polarization. Int. Immunopharmacol. 2017, 48, 146-158. [CrossRef] [PubMed]

198. Ryo, A.; Suizu, F.; Yoshida, Y.; Perrem, K.; Liou, Y.C.; Wulf, G.; Rottapel, R.; Yamaoka, S.; Lu, K.P. Regulation of NF-kB signaling by Pin1-dependent prolyl isomerization and ubiquitin-mediated proteolysis of p65/RelA. Mol. Cell 2003, 12, 1413-1426. [CrossRef]

199. Strebovsky, J.; Walker, P.; Lang, R.; Dalpke, A.H. Suppressor of cytokine signaling 1 (SOCS1) limits NFkB signaling by decreasing $\mathrm{p} 65$ stability within the cell nucleus. FASEB J. 2011, 25, 863-874. [CrossRef] [PubMed]

200. Liu, Y.; Liu, X.; Hua, W.; Wei, Q.; Fang, X.; Zhao, Z.; Ge, C.; Liu, C.; Chen, C.; Tao, Y.; et al. Berberine inhibits macrophage M1 polarization via AKT1/SOCS1/NF-kB signaling pathway to protect against DSS-induced colitis. Int. Immunopharmacol. 2018, 57, 121-131. [CrossRef] [PubMed]

201. García, J.A.; Volt, H.; Venegas, C.; Doerrier, C.; Escames, G.; López, L.C.; Acuña-Castroviejo, D. Disruption of the NF- $\mathrm{kB} / \mathrm{NLRP3}$ connection by melatonin requires retinoid-related orphan receptor- $\alpha$ and blocks the septic response in mice. FASEB J. 2015, 29, 3863-3875. [CrossRef] [PubMed]

202. Nejati Moharrami, N.; Bjørkøy Tande, E.; Ryan, L.; Espevik, T.; Boyartchuk, V. ROR $\alpha$ controls inflammatory state of human macrophages. PLoS ONE 2018, 13, e0207374. [CrossRef] [PubMed]

203. Slominski, A.T.; Kim, T.K.; Takeda, Y.; Janjetovic, Z.; Brozyna, A.A.; Skobowiat, C.; Wang, J.; Postlethwaite, A.; Li, W.; Tuckey, R.C.; et al. $\operatorname{ROR} \alpha$ and $\operatorname{ROR} \gamma$ are expressed in human skin and serve as receptors for endogenously produced noncalcemic 20-hydroxy- and 20,23-dihydroxyvitamin D. FASEB J. 2014, 28, 2775-2789. [CrossRef] [PubMed]

204. Slominski, A.T.; Zmijewski, M.A.; Jetten, A.M. ROR $\alpha$ is not a receptor for melatonin (response to DOI 10.1002/bies.201600018). BioEssays 2016, 38, 1193-1194. [CrossRef] [PubMed]

205. Zhang, S.; Gao, L.; Liu, X.; Lu, T.; Xie, C.; Jia, J. Resveratrol attenuates microglial activation via SIRT1-SOCS1 pathway. Evid. Based Complement. Alternat. Med. 2017, 2017, 8791832. [CrossRef] [PubMed]

206. Warren, K.J.; Fang, X.; Gowda, N.M.; Thompson, J.J.; Heller, N.M. The TORC1-activated proteins, p70S6K and GRB10, regulate IL-4 signaling and M2 macrophage polarization by modulating phosphorylation of insulin receptor substrate-2. J. Biol. Chem. 2016, 291, 24922-24930. [CrossRef] [PubMed]

207. Klinge, C.M. Non-coding RNAs in breast cancer: Intracellular and intercellular communication. Noncoding RNA 2018, 4, 40. [CrossRef] [PubMed]

208. Kufel, J.; Grzechnik, P. Small nucleolar RNAs tell a different tale. Trends Genet. 2019, 35, 104-117. [CrossRef] [PubMed]

209. Hardeland, R. On the relationships between lncRNAs and other orchestrating regulators: Role of the circadian system. Epigenomes 2018, 2, 9. [CrossRef]

210. Czech, B.; Munafò, M.; Ciabrelli, F.; Eastwood, E.L.; Fabry, M.H.; Kneuss, E.; Hannon, G.J. piRNA-guided genome defense: From biogenesis to silencing. Annu. Rev. Genet. 2018, 52, 131-157. [CrossRef] [PubMed]

211. Hardeland, R. Intercellular communication via exosomal and ectosomal microRNAs: Facing a jungle of countless microRNAs and targets. In Mini-Reviews in Recent Melatonin Research; Hardeland, R., Ed.; Cuvillier: Göttingen, Germany, 2017; pp. 109-122, ISBN 978-3-7369-9677-9.

212. Hardeland, R. Exosomal and ectosomal noncoding RNAs in cancer-More than diagnostic and prognostic markers. Open Acc. J. Oncol. Med. 2018, 2, 000144.

213. Hardeland, R. Melatonin, noncoding RNAs, messenger RNA stability and epigenetics—Evidence, hints, gaps and perspectives. Int. J. Mol. Sci. 2014, 15, 18221-18252. [CrossRef] [PubMed]

214. Hardeland, R. Interactions of melatonin and microRNAs. Biochem. Mol. Biol. J. 2018, 4, 7. [CrossRef] 
215. Hardeland, R. Melatonin and chromatin. Melatonin Res. 2019, 2, 67-93. [CrossRef]

216. Mann, M.; Mehta, A.; Zhao, J.L.; Lee, K.; Marinov, G.K.; Garcia-Flores, Y.; Lu, L.F.; Rudensky, A.Y.; Baltimore, D. An NF-kB-microRNA regulatory network tunes macrophage inflammatory responses. Nat. Commun. 2017, 8, 851. [CrossRef] [PubMed]

217. Yang, Y.; Liu, D.; Xi, Y.; Li, J.; Liu, B.; Li, J. Upregulation of miRNA-140-5p inhibits inflammatory cytokines in acute lung injury through the MyD88/NF-KB signaling pathway by targeting TLR4. Exp. Ther. Med. 2018, 16, 3913-3920. [CrossRef] [PubMed]

218. Zhao, G.; Zhang, T.; Wu, H.; Jiang, K.; Qiu, C.; Deng, G. MicroRNA let-7c improves LPS-induced outcomes of endometritis by suppressing NF- $\mathrm{KB}$ signaling. Inflammation 2018. [CrossRef] [PubMed]

219. Zheng, D.; Zang, Y.; Xu, H.; Wang, Y.; Cao, X.; Wang, T.; Pan, M.; Shi, J.; Li, X. MicroRNA-214 promotes the calcification of human aortic valve interstitial cells through the acceleration of inflammatory reactions with activated MyD88/NF-kB signaling. Clin. Res. Cardiol. 2018. [CrossRef] [PubMed]

220. Garavelli, S.; De Rosa, V.; de Candia, P. The multifaceted interface between cytokines and microRNAs: An ancient mechanism to regulate the good and the bad of inflammation. Front. Immunol. 2018, 9, 3012. [CrossRef] [PubMed]

221. Lee, S.E.; Kim, S.J.; Youn, J.P.; Hwang, S.Y.; Park, C.S.; Park, Y.S. MicroRNA and gene expression analysis of melatonin-exposed breast cancer cell lines indicating involvement of the anticancer effect. J. Pineal Res. 2011, 51, 345-352. [CrossRef] [PubMed]

222. Hardeland, R. Melatonin and microRNAs: An emerging field. In Mini-Reviews in Recent Melatonin Research; Hardeland, R., Ed.; Cuvillier: Göttingen, Germany, 2017; pp. 105-108, ISBN 978-3-7369-9677-9.

223. Koltai, E.; Bori, Z.; Osvath, P.; Ihasz, F.; Peter, S.; Toth, G.; Degens, H.; Rittweger, J.; Boldogh, I.; Radak, Z. Master athletes have higher miR-7, SIRT3 and SOD2 expression in skeletal muscle than age-matched sedentary controls. Redox Biol. 2018, 19, 46-51. [CrossRef] [PubMed]

224. Kabaria, S.; Choi, D.C.; Chaudhuri, A.D.; Jain, M.R.; Li, H.; Junn, E. MicroRNA-7 activates Nrf2 pathway by targeting Keap1 expression. Free Radic. Biol. Med. 2015, 89, 548-556. [CrossRef] [PubMed]

225. Choi, D.C.; Chae, Y.J.; Kabaria, S.; Chaudhuri, A.D.; Jain, M.R.; Li, H.; Mouradian, M.M.; Junn, E. MicroRNA-7 protects against 1-methyl-4-phenylpyridinium-induced cell death by targeting RelA. J. Neurosci. 2014, 34, 12725-12737. [CrossRef] [PubMed]

226. Zhao, X.D.; Lu, Y.Y.; Guo, H.; Xie, H.H.; He, L.J.; Shen, G.F.; Zhou, J.F.; Li, T.; Hu, S.J.; Zhou, L.; et al. MicroRNA-7/NF-kB signaling regulatory feedback circuit regulates gastric carcinogenesis. J. Cell Biol. 2015, 210, 613-627. [CrossRef] [PubMed]

227. Giles, K.M.; Brown, R.A.; Ganda, C.; Podgorny, M.J.; Candy, P.A.; Wintle, L.C.; Richardson, K.L.; Kalinowski, F.C.; Stuart, L.M.; Epis, M.R.; et al. microRNA-7-5p inhibits melanoma cell proliferation and metastasis by suppressing RelA/NF-кB. Oncotarget 2016, 7, 31663-31680. [CrossRef] [PubMed]

228. Saunders, L.R.; Sharma, A.D.; Tawney, J.; Nakagawa, M.; Okita, K.; Yamanaka, S.; Willenbring, H.; Verdin, E. miRNAs regulate SIRT1 expression during mouse embryonic stem cell differentiation and in adult mouse tissues. Aging 2010, 2, 415-431. [CrossRef] [PubMed]

229. Ramachandran, D.; Roy, U.; Garg, S.; Ghosh, S.; Pathak, S.; Kolthur-Seetharam, U. Sirt1 and mir-9 expression is regulated during glucose-stimulated insulin secretion in pancreatic $\beta$-islets. FEBS J. 2011, 278, 1167-1174. [CrossRef] [PubMed]

230. Schonrock, N.; Humphreys, D.T.; Preiss, T.; Götz, J. Target gene repression mediated by miRNAs miR-181c and miR-9 both of which are down-regulated by amyloid- $\beta$. J. Mol. Neurosci. 2012, 46, 324-335. [CrossRef] [PubMed]

231. Ao, R.; Wang, Y.; Tong, J.; Wang, B.F. Altered microRNA-9 expression level is directly correlated with pathogenesis of nonalcoholic fatty liver disease by targeting Onecut2 and SIRT1. Med. Sci. Monit. 2016, 22, 3804-3819. [CrossRef] [PubMed]

232. D'Adamo, S.; Cetrullo, S.; Guidotti, S.; Borzì, R.M.; Flamigni, F. Hydroxytyrosol modulates the levels of microRNA-9 and its target sirtuin-1 thereby counteracting oxidative stress-induced chondrocyte death. Osteoarthritis Cartilage 2017, 25, 600-610. [CrossRef] [PubMed]

233. Zhou, L.; Fu, L.; Lv, N.; Chen, X.S.; Liu, J.; Li, Y.; Xu, Q.Y.; Huang, S.; Zhang, X.D.; Dou, L.P.; et al. A minicircuitry comprised of microRNA-9 and SIRT1 contributes to leukemogenesis in $\mathrm{t}(8 ; 21)$ acute myeloid leukemia. Eur. Rev. Med. Pharmacol. Sci. 2017, 21, 786-794. [PubMed] 
234. Owczarz, M.; Budzinska, M.; Domaszewska-Szostek, A.; Borkowska, J.; Polosak, J.; Gewartowska, M.; Slusarczyk, P.; Puzianowska-Kuznicka, M. miR-34a and miR-9 are overexpressed and SIRT genes are downregulated in peripheral blood mononuclear cells of aging humans. Exp. Biol. Med. 2017, 242, 1453-1461. [CrossRef] [PubMed]

235. Bu, P.; Luo, C.; He, Q.; Yang, P.; Li, X.; Xu, D. MicroRNA-9 inhibits the proliferation and migration of malignant melanoma cells via targeting sirtuin 1. Exp. Ther. Med. 2017, 14, 931-938. [CrossRef] [PubMed]

236. Khosravi, A.; Alizadeh, S.; Jalili, A.; Shirzad, R.; Saki, N. The impact of Mir-9 regulation in normal and malignant hematopoiesis. Oncol. Rev. 2018, 12, e348. [CrossRef] [PubMed]

237. Rushworth, S.A.; Murray, M.Y.; Barrera, L.N.; Heasman, S.A.; Zaitseva, L.; MacEwan, D.J. Understanding the role of miRNA in regulating NF-kB in blood cancer. Am. J. Cancer Res. 2012, 2, 65-74. [PubMed]

238. Wang, L.Q.; Kwong, Y.L.; Kho, C.S.; Wong, K.F.; Wong, K.Y.; Ferracin, M.; Calin, G.A.; Chim, C.S. Epigenetic inactivation of miR-9 family microRNAs in chronic lymphocytic leukemia-Implications on constitutive activation of NFkB pathway. Mol. Cancer 2013, 12, 173. [CrossRef] [PubMed]

239. Zhang, Z.X.; Liu, Z.Q.; Jiang, B.; Lu, X.Y.; Ning, X.F.; Yuan, C.T.; Wang, A.L. BRAF activated non-coding RNA (BANCR) promoting gastric cancer cells proliferation via regulation of NF-kB1. Biochem. Biophys. Res. Commun. 2015, 465, 225-231. [CrossRef] [PubMed]

240. Chakraborty, S.; Zawieja, D.C.; Davis, M.J.; Muthuchamy, M. MicroRNA signature of inflamed lymphatic endothelium and role of miR-9 in lymphangiogenesis and inflammation. Am. J. Physiol. Cell Physiol. 2015, 309, C680-C692. [CrossRef] [PubMed]

241. Gu, R.; Liu, N.; Luo, S.; Huang, W.; Zha, Z.; Yang, J. MicroRNA-9 regulates the development of knee osteoarthritis through the NF-kappaB1 pathway in chondrocytes. Medicine 2016, 95, e4315. [CrossRef] [PubMed]

242. Qian, D.; Wei, G.; Xu, C.; He, Z.; Hua, J.; Li, J.; Hu, Q.; Lin, S.; Gong, J.; Meng, H.; et al. Bone marrow-derived mesenchymal stem cells (BMSCs) repair acute necrotized pancreatitis by secreting microRNA- 9 to target the NF-кB1/p50 gene in rats. Sci. Rep. 2017, 7, 581. [CrossRef] [PubMed]

243. Yao, H.; Ma, R.; Yang, L.; Hu, G.; Chen, X.; Duan, M.; Kook, Y.; Niu, F.; Liao, K.; Fu, M.; et al. MiR-9 promotes microglial activation by targeting MCPIP1. Nat. Commun. 2014, 5, 4386. [CrossRef] [PubMed]

244. Huang, G.; Liu, X.; Zhao, X.; Zhao, J.; Hao, J.; Ren, J.; Chen, Y. MiR-9 promotes multiple myeloma progression by regulating TRIM56/NF-кB pathway. Cell Biol. Int. 2019. [CrossRef] [PubMed]

245. Zhu, M.; Zhou, X.; Du, Y.; Huang, Z.; Zhu, J.; Xu, J.; Cheng, G.; Shu, Y.; Liu, P.; Zhu, W.; et al. miR-20a induces cisplatin resistance of a human gastric cancer cell line via targeting CYLD. Mol. Med. Rep. 2016, 14, 1742-1750. [CrossRef] [PubMed]

246. Liu, Z.; Yu, H.; Guo, Q. MicroRNA-20a promotes inflammation via the nuclear factor- $\kappa \mathrm{B}$ signaling pathway in pediatric pneumonia. Mol. Med. Rep. 2018, 17, 612-617. [CrossRef] [PubMed]

247. Lin, Q.; Geng, Y.; Zhao, M.; Lin, S.; Zhu, Q.; Tian, Z. MiR-21 regulates TNF- $\alpha$-induced CD40 expression via the SIRT1-NF-кB pathway in renal inner medullary collecting duct cells. Cell. Physiol. Biochem. 2017, 41, 124-136. [CrossRef] [PubMed]

248. Kim, S.J.; Kang, H.S.; Lee, J.H.; Park, J.H.; Jung, C.H.; Bae, J.H.; Oh, B.C.; Song, D.K.; Baek, W.K.; Im, S.S. Melatonin ameliorates ER stress-mediated hepatic steatosis through miR-23a in the liver. Biochem. Biophys. Res. Commun. 2015, 458, 462-469. [CrossRef] [PubMed]

249. Weinberg, R.B.; Mufson, E.J.; Counts, S.E. Evidence for a neuroprotective microRNA pathway in amnestic mild cognitive impairment. Front. Neurosci. 2015, 9, 430. [CrossRef] [PubMed]

250. Sruthi, T.V.; Edatt, L.; Raji, G.R.; Kunhiraman, H.; Shankar, S.S.; Shankar, V.; Ramachandran, V.; Poyyakkara, A.; Kumar, S.V.B. Horizontal transfer of miR-23a from hypoxic tumor cell colonies can induce angiogenesis. J. Cell. Physiol. 2018, 233, 3498-3514. [CrossRef] [PubMed]

251. Luo, H.; Han, Y.; Liu, J.; Zhang, Y. Identification of microRNAs in granulosa cells from patients with different levels of ovarian reserve function and the potential regulatory function of miR-23a in granulosa cell apoptosis. Gene 2019, 686, 250-260. [CrossRef] [PubMed]

252. Khan, A.U.H.; Rathore, M.G.; Allende-Vega, N.; Vo, D.N.; Belkhala, S.; Orecchioni, S.; Talarico, G.; Bertolini, F.; Cartron, G.; Lecellier, C.H.; et al. Human leukemic cells performing oxidative phosphorylation (OXPHOS) generate an antioxidant response independently of reactive oxygen species (ROS) production. EBioMedicine 2015, 3, 43-53. [CrossRef] [PubMed] 
253. Zhang, D.; Qiu, X.; Li, J.; Zheng, S.; Li, L.; Zhao, H. MiR-23a-3p-regulated abnormal acetylation of FOXP3 induces regulatory $\mathrm{T}$ cell function defect in Graves' disease. Biol. Chem. 2018. [CrossRef] [PubMed]

254. Zhao, S.; Li, T.; Li, J.; Lu, Q.; Han, C.; Wang, N.; Qiu, Q.; Cao, H.; Xu, X.; Chen, H.; et al. miR-23b-3p induces the cellular metabolic memory of high glucose in diabetic retinopathy through a SIRT1-dependent signalling pathway. Diabetologia 2016, 59, 644-654. [CrossRef] [PubMed]

255. Mori, F.; Ferraiuolo, M.; Santoro, R.; Sacconi, A.; Goeman, F.; Pallocca, M.; Pulito, C.; Korita, E.; Fanciulli, M.; Muti, P.; et al. Multitargeting activity of miR-24 inhibits long-term melatonin anticancer effects. Oncotarget 2016, 7, 20532-20548. [CrossRef] [PubMed]

256. Tong, X.; Wang, X.; Wang, C.; Li, L. Elevated levels of serum MiR-152 and miR-24 in uterine sarcoma: Potential for inducing autophagy via SIRT1 and deacetylated LC3. Br. J. Biomed. Sci. 2018, 75, 7-12. [CrossRef] [PubMed]

257. Xiao, X.; Lu, Z.; Lin, V.; May, A.; Shaw, D.H.; Wang, Z.; Che, B.; Tran, K.; Du, H.; Shaw, P.X. MicroRNA $\mathrm{miR}-24-3 \mathrm{p}$ reduces apoptosis and regulates Keap1-Nrf2 pathway in mouse cardiomyocytes responding to ischemia/reperfusion injury. Oxid. Med. Cell. Longev. 2018, 2018, 7042105. [CrossRef] [PubMed]

258. Xie, Q.; Wei, M.; Kang, X.; Liu, D.; Quan, Y.; Pan, X.; Liu, X.; Liao, D.; Liu, J.; Zhang, B. Reciprocal inhibition between miR-26a and NF-kB regulates obesity-related chronic inflammation in chondrocytes. Biosci. Rep. 2015, 35, e00204. [CrossRef] [PubMed]

259. Thulasingam, S.; Massilamany, C.; Gangaplara, A.; Dai, H.; Yarbaeva, S.; Subramaniam, S.; Riethoven, J.J.; Eudy, J.; Lou, M.; Reddy, J. miR-27b*, an oxidative stress-responsive microRNA modulates nuclear factor- $\mathrm{kB}$ pathway in RAW 264.7 cells. Mol. Cell. Biochem. 2011, 352, 181-188. [CrossRef] [PubMed]

260. Kurtz, C.L.; Fannin, E.E.; Toth, C.L.; Pearson, D.S.; Vickers, K.C.; Sethupathy, P. Inhibition of miR-29 has a significant lipid-lowering benefit through suppression of lipogenic programs in liver. Sci. Rep. 2015, 5, 12911. [CrossRef] [PubMed]

261. Zhou, L.; Xu, D.Y.; Sha, W.G.; Shen, L.; Lu, G.Y.; Yin, X.; Wang, M.J. High glucose induces renal tubular epithelial injury via Sirt1/NF-kappaB/microR-29/Keap1 signal pathway. J. Transl. Med. 2015, 13, 352. [CrossRef] [PubMed]

262. Wei, R.; Zhang, R.; Li, H.; Li, H.; Zhang, S.; Xie, Y.; Shen, L.; Chen, F. MiR-29 Targets PUMA to suppress oxygen and glucose deprivation/reperfusion (OGD/R)-induced cell death in hippocampal neurons. Curr. Neurovasc. Res. 2018, 15, 47-54. [CrossRef] [PubMed]

263. Egan Benova, T.; Viczenczova, C.; Szeiffova Bacova, B.; Knezl, V.; Dosenko, V.; Rauchova, H.; Zeman, M.; Reiter, R.J.; Tribulova, N. Obesity-associated alterations in cardiac connexin-43 and PKC signaling are attenuated by melatonin and omega-3 fatty acids in female rats. Mol. Cell. Biochem. 2018. [CrossRef] [PubMed]

264. Guan, Y.; Rao, Z.; Chen, C. miR-30a suppresses lung cancer progression by targeting SIRT1. Oncotarget 2017, 9, 4924-4934. [CrossRef] [PubMed]

265. Wan, Q.; Zhou, Z.; Ding, S.; He, J. The miR-30a negatively regulates IL-17-mediated signal transduction by targeting Traf3ip2. J. Interferon Cytokine Res. 2015, 35, 917-923. [CrossRef] [PubMed]

266. Volkmann, I.; Kumarswamy, R.; Pfaff, N.; Fiedler, J.; Dangwal, S.; Holzmann, A.; Batkai, S.; Geffers, R.; Lother, A.; Hein, L.; et al. MicroRNA-mediated epigenetic silencing of sirtuin1 contributes to impaired angiogenic responses. Circ. Res. 2013, 113, 997-1003. [CrossRef] [PubMed]

267. Kumarswamy, R.; Volkmann, I.; Beermann, J.; Napp, L.C.; Jabs, O.; Bhayadia, R.; Melk, A.; Ucar, A.; Chowdhury, K.; Lorenzen, J.M.; et al. Vascular importance of the miR-212/132 cluster. Eur. Heart J. 2014, 35, 3224-3231. [CrossRef] [PubMed]

268. Meng, F.; Dai, E.; Yu, X.; Zhang, Y.; Chen, X.; Liu, X.; Wang, S.; Wang, L.; Jiang, W. Constructing and characterizing a bioactive small molecule and microRNA association network for Alzheimer's disease. J. R. Soc. Interface 2013, 11, 20131057. [CrossRef] [PubMed]

269. Rajbhandari, R.; McFarland, B.C.; Patel, A.; Gerigk, M.; Gray, G.K.; Fehling, S.C.; Bredel, M.; Berbari, N.F.; Kim, H.; Marks, M.P.; et al. Loss of tumor suppressive microRNA-31 enhances TRADD/NF- $\mathrm{B}$ signaling in glioblastoma. Oncotarget 2015, 6, 17805-17816. [CrossRef] [PubMed]

270. Carloni, S.; Favrais, G.; Saliba, E.; Albertini, M.C.; Chalon, S.; Longini, M.; Gressens, P.; Buonocore, G.; Balduini, W. Melatonin modulates neonatal brain inflammation through endoplasmic reticulum stress, autophagy, and miR-34a/silent information regulator 1 pathway. J. Pineal Res. 2016, 61, 370-830. [CrossRef] [PubMed] 
271. Pogribny, I.P.; Muskhelishvili, L.; Tryndyak, V.P.; Beland, F.A. The tumor-promoting activity of 2-acetylaminofluorene is associated with disruption of the p53 signaling pathway and the balance between apoptosis and cell proliferation. Toxicol. Appl. Pharmacol. 2009, 235, 305-311. [CrossRef] [PubMed]

272. Tabuchi, T.; Satoh, M.; Itoh, T.; Nakamura, M. MicroRNA-34a regulates the longevity-associated protein SIRT1 in coronary artery disease: Effect of statins on SIRT1 and microRNA-34a expression. Clin. Sci. 2012, 123, 161-171. [CrossRef] [PubMed]

273. Roy, A.; Zhang, M.; Saad, Y.; Kolattukudy, P.E. Antidicer RNAse activity of monocyte chemotactic protein-induced protein-1 is critical for inducing angiogenesis. Am. J. Physiol. Cell Physiol. 2013, 305, C1021-C1032. [CrossRef] [PubMed]

274. Khee, S.G.; Yusof, Y.A.; Makpol, S. Expression of senescence-associated microRNAs and target genes in cellular aging and modulation by tocotrienol-rich fraction. Oxid. Med. Cell. Longev. 2014, 2014, 725929. [PubMed]

275. Karbasforooshan, H.; Karimi, G. The role of SIRT1 in diabetic retinopathy. Biomed. Pharmacother. 2018, 97, 190-194. [CrossRef] [PubMed]

276. Rossi, S.; Di Filippo, C.; Gesualdo, C.; Testa, F.; Trotta, M.C.; Maisto, R.; Ferraro, B.; Ferraraccio, F.; Accardo, M.; Simonelli, F.; et al. Interplay between intravitreal RvD1 and local endogenous sirtuin-1 in the protection from endotoxin-induced uveitis in rats. Mediat. Inflamm. 2015, 2015, 126408. [CrossRef] [PubMed]

277. Gao, A.M.; Zhang, X.Y.; Ke, Z.P. Apigenin sensitizes BEL-7402/ADM cells to doxorubicin through inhibiting miR-101/Nrf2 pathway. Oncotarget 2017, 8, 82085-82091. [CrossRef] [PubMed]

278. Raji, G.R.; Sruthi, T.V.; Edatt, L.; Haritha, K.; Sharath Shankar, S.; Sameer Kumar, V.B. Horizontal transfer of $\mathrm{miR}-106 \mathrm{a} / \mathrm{b}$ from cisplatin resistant hepatocarcinoma cells can alter the sensitivity of cervical cancer cells to cisplatin. Cell. Signal. 2017, 38, 146-158. [CrossRef] [PubMed]

279. Heyn, J.; Luchting, B.; Hinske, L.C.; Hübner, M.; Azad, S.C.; Kreth, S. miR-124a and miR-155 enhance differentiation of regulatory $\mathrm{T}$ cells in patients with neuropathic pain. J. Neuroinflamm. 2016, 13, 248. [CrossRef] [PubMed]

280. Kim, S.W.; Ramasamy, K.; Bouamar, H.; Lin, A.P.; Jiang, D.; Aguiar, R.C. MicroRNAs miR-125a and miR-125b constitutively activate the NF- $\mathrm{kB}$ pathway by targeting the tumor necrosis factor alpha-induced protein 3 (TNFAIP3, A20). Proc. Natl. Acad. Sci. USA 2012, 109, 7865-7870. [CrossRef] [PubMed]

281. Haemmig, S.; Baumgartner, U.; Glück, A.; Zbinden, S.; Tschan, M.P.; Kappeler, A.; Mariani, L.; Vajtai, I.; Vassella, E. miR-125b controls apoptosis and temozolomide resistance by targeting TNFAIP3 and NKIRAS2 in glioblastomas. Cell Death Dis. 2014, 5, e1279. [CrossRef] [PubMed]

282. Parisi, C.; Napoli, G.; Amadio, S.; Spalloni, A.; Apolloni, S.; Longone, P.; Volonté, C. MicroRNA-125b regulates microglia activation and motor neuron death in ALS. Cell Death Differ. 2016, 23, 531-541. [CrossRef] [PubMed]

283. Zheng, Z.; Qu, J.Q.; Yi, H.M.; Ye, X.; Huang, W.; Xiao, T.; Li, J.Y.; Wang, Y.Y.; Feng, J.; Zhu, J.F.; et al. MiR-125b regulates proliferation and apoptosis of nasopharyngeal carcinoma by targeting A20/NF- $\mathrm{kB}$ signaling pathway. Cell Death Dis. 2017, 8, e2855. [CrossRef] [PubMed]

284. Xue, N.; Qi, L.; Zhang, G.; Zhang, Y. miRNA-125b regulates osteogenic differentiation of periodontal ligament cells through NKIRAS2/NF-kB pathway. Cell. Physiol. Biochem. 2018, 48, 1771-1781. [CrossRef] [PubMed]

285. Wang, D.; Cao, L.; Xu, Z.; Fang, L.; Zhong, Y.; Chen, Q.; Luo, R.; Chen, H.; Li, K.; Xiao, S. MiR-125b reduces porcine reproductive and respiratory syndrome virus replication by negatively regulating the NF- $\mathrm{KB}$ pathway. PLOS ONE 2013, 8, e55838. [CrossRef] [PubMed]

286. Wang, X.; Ha, T.; Zou, J.; Ren, D.; Liu, L.; Zhang, X.; Kalbfleisch, J.; Gao, X.; Williams, D.; Li, C. MicroRNA-125b protects against myocardial ischaemia/reperfusion injury via targeting p53-mediated apoptotic signalling and TRAF6. Cardiovasc. Res. 2014, 102, 385-395. [CrossRef] [PubMed]

287. Ma, H.; Wang, X.; Ha, T.; Gao, M.; Liu, L.; Wang, R.; Yu, K.; Kalbfleisch, J.H.; Kao, R.L.; Williams, D.L.; et al. MicroRNA-125b prevents cardiac dysfunction in polymicrobial sepsis by targeting TRAF6-mediated nuclear factor $\mathrm{kB}$ activation and p53-mediated apoptotic signaling. J. Infect. Dis. 2016, 214, 1773-1783. [CrossRef] [PubMed]

288. Wang, Y.; Tang, P.; Chen, Y.; Chen, J.; Ma, R.; Sun, L. Overexpression of microRNA-125b inhibits human acute myeloid leukemia cells invasion, proliferation and promotes cells apoptosis by targeting NF- $\mathrm{B}$ signaling pathway. Biochem. Biophys. Res. Commun. 2017, 488, 60-66. [CrossRef] [PubMed] 
289. Jia, J.; Wang, J.; Zhang, J.; Cui, M.; Sun, X.; Li, Q.; Zhao, B. MiR-125b inhibits LPS-induced inflammatory injury via targeting MIP-1 $\alpha$ in chondrogenic cell ATDC5. Cell. Physiol. Biochem. 2018, 45, 2305-2316. [CrossRef] [PubMed]

290. Togliatto, G.; Trombetta, A.; Dentelli, P.; Gallo, S.; Rosso, A.; Cotogni, P.; Granata, R.; Falcioni, R.; Delale, T.; Ghigo, E.; et al. Unacylated ghrelin induces oxidative stress resistance in a glucose intolerance and peripheral artery disease mouse model by restoring endothelial cell miR-126 expression. Diabetes 2015, 64, 1370-1382. [CrossRef] [PubMed]

291. Oglesby, I.K.; Bray, I.M.; Chotirmall, S.H.; Stallings, R.L.; O’Neill, S.J.; McElvaney, N.G.; Greene, C.M. miR-126 is downregulated in cystic fibrosis airway epithelial cells and regulates TOM1 expression. J. Immunol. 2010, 184, 1702-1709. [CrossRef] [PubMed]

292. Feng, X.; Wang, H.; Ye, S.; Guan, J.; Tan, W.; Cheng, S.; Wei, G.; Wu, W.; Wu, F.; Zhou, Y. Up-regulation of microRNA-126 may contribute to pathogenesis of ulcerative colitis via regulating NF-kappaB inhibitor IкB $\alpha$. PLoS ONE 2012, 7, e52782. [CrossRef] [PubMed]

293. Feng, X.; Tan, W.; Cheng, S.; Wang, H.; Ye, S.; Yu, C.; He, Y.; Zeng, J.; Cen, J.; Hu, J.; et al. Upregulation of microRNA-126 in hepatic stellate cells may affect pathogenesis of liver fibrosis through the NF- $\mathrm{kB}$ pathway. DNA Cell Biol. 2015, 34, 470-480. [CrossRef] [PubMed]

294. Adlakha, Y.K.; Saini, N. miR-128 exerts pro-apoptotic effect in a p53 transcription-dependent and -independent manner via PUMA-Bak axis. Cell Death Dis. 2013, 4, e542. [CrossRef] [PubMed]

295. Lian, B.; Yang, D.; Liu, Y.; Shi, G.; Li, J.; Yan, X.; Jin, K.; Liu, X.; Zhao, J.; Shang, W.; et al. miR-128 targets the SIRT1/ROS/DR5 pathway to sensitize colorectal cancer to TRAIL-induced apoptosis. Cell. Physiol. Biochem. 2018, 49, 2151-2162. [CrossRef] [PubMed]

296. Pan, S.; Cui, Y.; Fu, Z.; Zhang, L.; Xing, H. MicroRNA-128 is involved in dexamethasone-induced lipid accumulation via repressing SIRT1 expression in cultured pig preadipocytes. J. Steroid Biochem. Mol. Biol. 2019, 186, 185-195. [CrossRef] [PubMed]

297. Xia, Z.; Meng, F.; Liu, Y.; Fang, Y.; Wu, X.; Zhang, C.; Liu, D.; Li, G. Decreased MiR-128-3p alleviates the progression of rheumatoid arthritis by up-regulating the expression of TNFAIP3. Biosci. Rep. 2018, 38, BSR20180540. [CrossRef] [PubMed]

298. Geng, L.; Zhang, T.; Liu, W.; Chen, Y. Inhibition of miR-128 abates A $\beta$-mediated cytotoxicity by targeting PPAR- $\gamma$ via NF-кB inactivation in primary mouse cortical neurons and Neuro2a cells. Yonsei Med. J. 2018, 59, 1096-1106. [CrossRef] [PubMed]

299. Ali, T.; Mushtaq, I.; Maryam, S.; Farhan, A.; Saba, K.; Jan, M.I.; Sultan, A.; Anees, M.; Duygu, B.; Hamera, S.; et al. Interplay of $\mathrm{N}$-acetyl cysteine and melatonin in regulating oxidative stress-induced cardiac hypertrophic factors and microRNAs. Arch. Biochem. Biophys. 2019, 661, 56-65. [CrossRef] [PubMed]

300. Liu, L.; Sun, T.; Liu, Z.; Chen, X.; Zhao, L.; Qu, G.; Li, Q. Traumatic brain injury dysregulates microRNAs to modulate cell signaling in rat hippocampus. PLoS ONE 2014, 9, e103948. [CrossRef] [PubMed]

301. Smith, E.J.; Shay, K.P.; Thomas, N.O.; Butler, J.A.; Finlay, L.F.; Hagen, T.M. Age-related loss of hepatic Nrf2 protein homeostasis: Potential role for heightened expression of miR-146a. Free Radic. Biol. Med. 2015, 89, 1184-1191. [CrossRef] [PubMed]

302. Kamali, K.; Korjan, E.S.; Eftekhar, E.; Malekzadeh, K.; Soufi, F.G. The role of miR-146a on NF-kB expression level in human umbilical vein endothelial cells under hyperglycemic condition. Bratisl. Lek. Listy 2016, 117, 376-380. [CrossRef] [PubMed]

303. Loubaki, L.; Chabot, D.; Paré, I.; Drouin, M.; Bazin, R. MiR-146a potentially promotes IVIg-mediated inhibition of TLR4 signaling in LPS-activated human monocytes. Immunol. Lett. 2017, 185, 64-73. [CrossRef] [PubMed]

304. An, R.; Feng, J.; Xi, C.; Xu, J.; Sun, L. miR-146a attenuates sepsis-induced myocardial dysfunction by suppressing IRAK1 and TRAF6 via targeting ErbB4 expression. Oxid. Med. Cell. Longev. 2018, 2018, 7163057. [CrossRef] [PubMed]

305. Lindeløv Vestergaard, A.; Heiner Bang-Berthelsen, C.; Fløyel, T.; Lucien Stahl, J.; Christen, L.; Taheri Sotudeh, F.; de Hemmer Horskjær, P.; Stensgaard Frederiksen, K.; Greek Kofod, F.; Bruun, C.; et al. MicroRNAs and histone deacetylase inhibition-mediated protection against inflammatory $\beta$-cell damage. PLoS ONE 2018, 13, e0203713. [CrossRef] [PubMed] 
306. Sang, W.; Wang, Y.; Zhang, C.; Zhang, D.; Sun, C.; Niu, M.; Zhang, Z.; Wei, X.; Pan, B.; Chen, W.; et al. MiR-150 impairs inflammatory cytokine production by targeting ARRB-2 after blocking CD28/B7 costimulatory pathway. Immunol. Lett. 2016, 172, 1-10. [CrossRef] [PubMed]

307. Xue, H.; Li, M.X. MicroRNA-150 protects against cigarette smoke-induced lung inflammation and airway epithelial cell apoptosis through repressing p53: MicroRNA-150 in CS-induced lung inflammation. Hum. Exp. Toxicol. 2018, 37, 920-928. [CrossRef] [PubMed]

308. Ma, Y.; Liu, Y.; Hou, H.; Yao, Y.; Meng, H. MiR-150 predicts survival in patients with sepsis and inhibits LPS-induced inflammatory factors and apoptosis by targeting NF- $\mathrm{KB} 1$ in human umbilical vein endothelial cells. Biochem. Biophys. Res. Commun. 2018, 500, 828-837. [CrossRef] [PubMed]

309. Luo, X.Y.; Zhu, X.Q.; Li, Y.; Wang, X.B.; Yin, W.; Ge, Y.S.; Ji, W.M. MicroRNA-150 restores endothelial cell function and attenuates vascular remodeling by targeting PTX3 through the NF- $\mathrm{KB}$ signaling pathway in mice with acute coronary syndrome. Cell Biol. Int. 2018. [CrossRef] [PubMed]

310. Gu, J.; Lu, Z.; Ji, C.; Chen, Y.; Liu, Y.; Lei, Z.; Wang, L.; Zhang, H.T.; Li, X. Melatonin inhibits proliferation and invasion via repression of miRNA-155 in glioma cells. Biomed. Pharmacother. 2017, 93, 969-975. [CrossRef]

311. Wang, Y.; Zheng, Z.J.; Jia, Y.J.; Yang, Y.L.; Xue, Y.M. Role of p53/miR-155-5p/sirt1 loop in renal tubular injury of diabetic kidney disease. J. Transl. Med. 2018, 16, 146. [CrossRef] [PubMed]

312. Wang, X.; Wang, B.; Zhao, J.; Liu, C.; Qu, X.; Li, Y. MiR-155 is involved in major depression disorder and antidepressant treatment via targeting SIRT1. Biosci. Rep. 2018, 38, 20181139. [CrossRef] [PubMed]

313. Wan, C.; Han, R.; Liu, L.; Zhang, F.; Li, F.; Xiang, M.; Ding, W. Role of miR-155 in fluorooctane sulfonate-induced oxidative hepatic damage via the Nrf2-dependent pathway. Toxicol. Appl. Pharmacol. 2016, 295, 85-93. [CrossRef] [PubMed]

314. Gu, S.; Lai, Y.; Chen, H.; Liu, Y.; Zhang, Z. miR-155 mediates arsenic trioxide resistance by activating Nrf2 and suppressing apoptosis in lung cancer cells. Sci. Rep. 2017, 7, 12155. [CrossRef] [PubMed]

315. Rodriguez-Ortiz, C.J.; Baglietto-Vargas, D.; Martinez-Coria, H.; LaFerla, F.M.; Kitazawa, M. Upregulation of miR-181 decreases c-Fos and SIRT-1 in the hippocampus of 3xTg-AD mice. J. Alzheimers Dis. 2014, 42, 1229-1238. [CrossRef] [PubMed]

316. Chen, X.Y.; Zhang, H.S.; Wu, T.C.; Sang, W.W.; Ruan, Z. Down-regulation of NAMPT expression by miR-182 is involved in Tat-induced HIV-1 long terminal repeat (LTR) transactivation. Int. J. Biochem. Cell Biol. 2013, 45, 292-298. [CrossRef] [PubMed]

317. Eyler, C.E.; Rich, J.N. Looking in the miR-ror: TGF- $\beta$-mediated activation of NF- $\mathrm{B}$ in glioma. J. Clin. Investig. 2012, 122, 3473-3475. [CrossRef] [PubMed]

318. Song, L.; Liu, L.; Wu, Z.; Li, Y.; Ying, Z.; Lin, C.; Wu, J.; Hu, B.; Cheng, S.Y.; Li, M.; et al. TGF- $\beta$ induces miR-182 to sustain NF-kB activation in glioma subsets. J. Clin. Investig. 2012, 122, 3563-3578. [CrossRef] [PubMed]

319. Guo, Y.; Liao, Y.; Jia, C.; Ren, J.; Wang, J.; Li, T. MicroRNA-182 promotes tumor cell growth by targeting transcription elongation factor A-like 7 in endometrial carcinoma. Cell. Physiol. Biochem. 2013, 32, 581-590. [CrossRef] [PubMed]

320. Ling, T.; Yu, F.; Cao, H. miR-182 controls cell growth in gastrointestinal stromal tumors by negatively regulating CYLD expression. Oncol. Rep. 2018, 40, 3705-3713. [CrossRef] [PubMed]

321. Liu, Y.; Li, L.N.; Guo, S.; Zhao, X.Y.; Liu, Y.Z.; Liang, C.; Tu, S.; Wang, D.; Li, L.; Dong, J.Z.; et al. Melatonin improves cardiac function in a mouse model of heart failure with preserved ejection fraction. Redox Biol. 2018, 18, 211-221. [CrossRef] [PubMed]

322. Wang, R.; Zhou, S.; Wu, P.; Li, M.; Ding, X.; Sun, L.; Xu, X.; Zhou, X.; Zhou, L.; Cao, C.; et al. Identifying involvement of H19-miR-675-3p-IGF1R and H19-miR-200a-PDCD4 in treating pulmonary hypertension with melatonin. Mol. Ther. Nucleic Acids 2018, 13, 44-54. [CrossRef] [PubMed]

323. Eades, G.; Yao, Y.; Yang, M.; Zhang, Y.; Chumsri, S.; Zhou, Q. miR-200a regulates SIRT1 expression and epithelial to mesenchymal transition (EMT)-like transformation in mammary epithelial cells. J. Biol. Chem. 2011, 286, 25992-26002. [CrossRef] [PubMed]

324. Pan, F.; Qiu, X.F.; Yu, W.; Zhang, Q.P.; Chen, Q.; Zhang, C.Y.; Chen, Y.; Pan, L.J.; Zhang, A.X.; Dai, Y.T. MicroRNA-200a is up-regulated in aged rats with erectile dysfunction and could attenuate endothelial function via SIRT1 inhibition. Asian J. Androl. 2016, 18, 74-79. [PubMed] 
325. Zhang, P.; Xu, L.; Guan, H.; Liu, L.; Liu, J.; Huang, Z.; Cao, X.; Liao, Z.; Xiao, H.; Li, Y. Beraprost sodium, a prostacyclin analogue, reduces fructose-induced hepatocellular steatosis in mice and in vitro via the microRNA-200a and SIRT1 signaling pathway. Metabolism 2017, 73, 9-21. [CrossRef] [PubMed]

326. Fu, H.; Song, W.; Chen, X.; Guo, T.; Duan, B.; Wang, X.; Tang, Y.; Huang, L.; Zhang, C. MiRNA-200a induce cell apoptosis in renal cell carcinoma by directly targeting SIRT1. Mol. Cell. Biochem. 2018, 437, 143-152. [CrossRef] [PubMed]

327. Salimian, N.; Peymani, M.; Ghaedi, K.; Nasr Esfahani, M.H. Modulation in miR-200a/SIRT1axis is associated with apoptosis in $\mathrm{MPP}^{+}$-induced SH-SY5Y cells. Gene 2018, 674, 25-30. [CrossRef] [PubMed]

328. Eades, G.; Yang, M.; Yao, Y.; Zhang, Y.; Zhou, Q. miR-200a regulates Nrf2 activation by targeting Keap1 mRNA in breast cancer cells. J. Biol. Chem. 2011, 286, 40725-40733. [CrossRef] [PubMed]

329. Murray-Stewart, T.; Hanigan, C.L.; Woster, P.M.; Marton, L.J.; Casero, R.A., Jr. Histone deacetylase inhibition overcomes drug resistance through a miRNA-dependent mechanism. Mol. Cancer Ther. 2013, 12, 2088-2099. [CrossRef] [PubMed]

330. Wei, J.; Zhang, Y.; Luo, Y.; Wang, Z.; Bi, S.; Song, D.; Dai, Y.; Wang, T.; Qiu, L.; Wen, L.; et al. Aldose reductase regulates miR-200a-3p/141-3p to coordinate Keap1-Nrf2, Tgf $31 / 2$, and Zeb1/2 signaling in renal mesangial cells and the renal cortex of diabetic mice. Free Radic. Biol. Med. 2014, 67, 91-102. [CrossRef] [PubMed]

331. Liu, Q.L.; Zhang, J.; Liu, X.; Gao, J.Y. Role of growth hormone in maturation and activation of dendritic cells via miR-200a and the Keap1/Nrf2 pathway. Cell Prolif. 2015, 48, 573-581. [CrossRef] [PubMed]

332. Liu, M.; Hu, C.; Xu, Q.; Chen, L.; Ma, K.; Xu, N.; Zhu, H. Methylseleninic acid activates Keap1/Nrf2 pathway via up-regulating miR-200a in human oesophageal squamous cell carcinoma cells. Biosci. Rep. 2015, 35, e00256. [CrossRef] [PubMed]

333. Sun, X.; Zuo, H.; Liu, C.; Yang, Y. Overexpression of miR-200a protects cardiomyocytes against hypoxia-induced apoptosis by modulating the kelch-like ECH-associated protein 1-nuclear factor erythroid 2-related factor 2 signaling axis. Int. J. Mol. Med. 2016, 38, 1303-1311. [CrossRef] [PubMed]

334. Wu, H.; Kong, L.; Tan, Y.; Epstein, P.N.; Zeng, J.; Gu, J.; Liang, G.; Kong, M.; Chen, X.; Miao, L.; et al. C66 ameliorates diabetic nephropathy in mice by both upregulating NRF2 function via increase in miR-200a and inhibiting miR-21. Diabetologia 2016, 59, 1558-1568. [CrossRef] [PubMed]

335. Zhao, S.; Mao, L.; Wang, S.G.; Chen, F.L.; Ji, F.; Fe, H.D. MicroRNA-200a activates Nrf2 signaling to protect osteoblasts from dexamethasone. Oncotarget 2017, 8, 104867-104876. [CrossRef] [PubMed]

336. Zhao, X.J.; Yu, H.W.; Yang, Y.Z.; Wu, W.Y.; Chen, T.Y.; Jia, K.K.; Kang, L.L.; Jiao, R.Q.; Kong, L.D. Polydatin prevents fructose-induced liver inflammation and lipid deposition through increasing miR-200a to regulate Keap1/Nrf2 pathway. Redox Biol. 2018, 18, 124-137. [CrossRef] [PubMed]

337. Shi, Z.; Hu, Z.; Chen, D.; Huang, J.; Fan, J.; Zhou, S.; Wang, X.; Hu, J.; Huang, F. MicroRNA-200a mediates nasopharyngeal carcinoma cell proliferation through the activation of nuclear factor-кB. Mol. Med. Rep. 2016, 13, 1732-1738. [CrossRef] [PubMed]

338. Zhang, Q.S.; Liu, W.; Lu, G.X. miR-200a-3p promotes $\beta$-Amyloid-induced neuronal apoptosis through down-regulation of SIRT1 in Alzheimer's disease. J. Biosci. 2017, 42, 397-404. [CrossRef] [PubMed]

339. Li, L.; Wang, Q.; Yuan, Z.; Chen, A.; Liu, Z.; Li, H.; Wang, Z. Long non-coding RNA H19 contributes to hypoxia-induced CPC injury by suppressing Sirt1 through miR-200a-3p. Acta Biochim. Biophys. Sin. 2018, 50, 950-959. [CrossRef] [PubMed]

340. Qi, J.; Qiao, Y.; Wang, P.; Li, S.; Zhao, W.; Gao, C. microRNA-210 negatively regulates LPS-induced production of proinflammatory cytokines by targeting NF-kB1 in murine macrophages. FEBS Lett. 2012, 586, 1201-1207. [CrossRef] [PubMed]

341. Zhang, D.; Cao, X.; Li, J.; Zhao, G. MiR-210 inhibits NF-kB signaling pathway by targeting DR6 in osteoarthritis. Sci. Rep. 2015, 5, 12775. [CrossRef] [PubMed]

342. Ramalinga, M.; Roy, A.; Srivastava, A.; Bhattarai, A.; Harish, V.; Suy, S.; Collins, S.; Kumar, D. MicroRNA-212 negatively regulates starvation induced autophagy in prostate cancer cells by inhibiting SIRT1 and is a modulator of angiogenesis and cellular senescence. Oncotarget 2015, 6, 34446-34457. [CrossRef] [PubMed]

343. Miao, H.; Zeng, H.; Gong, H. microRNA-212 promotes lipid accumulation and attenuates cholesterol efflux in THP-1 human macrophages by targeting SIRT1. Gene 2018, 643, 55-60. [CrossRef] [PubMed]

344. Li, D.; Bai, L.; Wang, T.; Xie, Q.; Chen, M.; Fu, Y.; Wen, Q. Function of miR-212 as a tumor suppressor in thyroid cancer by targeting SIRT1. Oncol. Rep. 2018, 39, 695-702. [CrossRef] [PubMed] 
345. Fiorentino, L.; Cavalera, M.; Mavilio, M.; Conserva, F.; Menghini, R.; Gesualdo, L.; Federici, M. Regulation of TIMP3 in diabetic nephropathy: A role for microRNAs. Acta Diabetol. 2013, 50, 965-969. [CrossRef] [PubMed]

346. Lu, Z.; Li, Y.; Takwi, A.; Li, B.; Zhang, J.; Conklin, D.J.; Young, K.H.; Martin, R.; Li, Y. miR-301a as an NF-kB activator in pancreatic cancer cells. EMBO J. 2011, 30, 57-67. [CrossRef] [PubMed]

347. Zhou, P.; Jiang, W.; Wu, L.; Chang, R.; Wu, K.; Wang, Z. miR-301a is a candidate oncogene that targets the homeobox gene Gax in human hepatocellular carcinoma. Dig. Dis. Sci. 2012, 57, 1171-1180. [CrossRef] [PubMed]

348. Huang, L.; Liu, Y.; Wang, L.; Chen, R.; Ge, W.; Lin, Z.; Zhang, Y.; Liu, S.; Shan, Y.; Lin, Q.; et al. Down-regulation of miR-301a suppresses pro-inflammatory cytokines in Toll-like receptor-triggered macrophages. Immunology 2013, 140, 314-322. [PubMed]

349. Ma, X.; Yan, F.; Deng, Q.; Li, F.; Lu, Z.; Liu, M.; Wang, L.; Conklin, D.J.; McCracken, J.; Srivastava, S.; et al. Modulation of tumorigenesis by the pro-inflammatory microRNA miR-301a in mouse models of lung cancer and colorectal cancer. Cell Discov. 2015, 1, 15005. [CrossRef] [PubMed]

350. Tavakolpour, V.; Shokri, G.; Naser Moghadasi, A.; Mozafari Nahavandi, P.; Hashemi, M.; Kouhkan, F. Increased expression of mir-301a in PBMCs of patients with relapsing-remitting multiple sclerosis is associated with reduced NKRF and PIAS3 expression levels and disease activity. J. Neuroimmunol. 2018, 325, 79-86. [CrossRef] [PubMed]

351. Wu, C.T.; Huang, Y.; Pei, Z.Y.; Xi, X.; Zhu, G.F. MicroRNA-326 aggravates acute lung injury in septic shock by mediating the NF-kB signaling pathway. Int. J. Biochem. Cell Biol. 2018, 101, 1-11. [CrossRef] [PubMed]

352. Shi, L.; Chen, Z.G.; Wu, L.L.; Zheng, J.J.; Yang, J.R.; Chen, X.F.; Chen, Z.Q.; Liu, C.L.; Chi, S.Y.; Zheng, J.Y.; et al. miR-340 reverses cisplatin resistance of hepatocellular carcinoma cell lines by targeting Nrf2-dependent antioxidant pathway. Asian Pac. J. Cancer Prev. 2014, 15, 10439-10444. [CrossRef] [PubMed]

353. Wu, L.L.; Cai, W.P.; Lei, X.; Shi, Q.; Lin, X.Y.; Shi, L. NRAL mediates cisplatin resistance in hepatocellular carcinoma via miR-340-5p/Nrf2 axis. J. Cell. Commun. Signal. 2018. [CrossRef] [PubMed]

354. Prins, S.A.; Przybycien-Szymanska, M.M.; Rao, Y.S.; Pak, T.R. Long-term effects of peripubertal binge EtOH exposure on hippocampal microRNA expression in the rat. PLoS ONE 2014, 9, e83166. [CrossRef] [PubMed]

355. Cai, B.; Ma, W.; Bi, C.; Yang, F.; Zhang, L.; Han, Z.; Huang, Q.; Ding, F.; Li, Y.; Yan, G.; et al. Long noncoding RNA H19 mediates melatonin inhibition of premature senescence of c-kit ${ }^{+}$cardiac progenitor cells by promoting miR-675. J. Pineal Res. 2016, 61, 82-95. [CrossRef] [PubMed]

356. Liu, J.; Zhu, L.; Xie, G.L.; Bao, J.F.; Yu, Q. Let-7 miRNAs modulate the activation of NF-kB by targeting TNFAIP3 and are involved in the pathogenesis of lupus nephritis. PLoS ONE 2015, 10, e0121256. [CrossRef] [PubMed]

357. Yang, S.; Tang, W.; He, Y.; Wen, L.; Sun, B.; Li, S. Long non-coding RNA and microRNA-675/let-7a mediates the protective effect of melatonin against early brain injury after subarachnoid hemorrhage via targeting TP53 and neural growth factor. Cell Death Dis. 2018, 9, 99. [CrossRef] [PubMed]

358. Lin, Z.; Ge, J.; Wang, Z.; Ren, J.; Wang, X.; Xiong, H.; Gao, J.; Zhang, Y.; Zhang, Q. Let-7e modulates the inflammatory response in vascular endothelial cells through ceRNA crosstalk. Sci. Rep. 2017, 7, 42498. [CrossRef] [PubMed]

359. Kumar, M.; Sahu, S.K.; Kumar, R.; Subuddhi, A.; Maji, R.K.; Jana, K.; Gupta, P.; Raffetseder, J.; Lerm, M.; Ghosh, Z.; et al. MicroRNA let-7 modulates the immune response to Mycobacterium tuberculosis infection via control of A20, an inhibitor of the NF-kB pathway. Cell Host Microbe 2015, 17, 345-356. [CrossRef] [PubMed]

360. Wang, Y.S.; His, E.; Cheng, H.Y.; Hsu, S.H.; Liao, Y.C.; Juo, S.H. Let-7g suppresses both canonical and non-canonical NF- $\mathrm{kB}$ pathways in macrophages leading to anti-atherosclerosis. Oncotarget 2017, 8 , 101026-101041. [PubMed]

361. Xie, H.; Lei, N.; Gong, A.Y.; Chen, X.M.; Hu, G. Cryptosporidium parvum induces SIRT1 expression in host epithelial cells through downregulating let-7i. Hum. Immunol. 2014, 75, 760-765. [CrossRef] [PubMed]

362. Sarver, A.L.; Sarver, A.E.; Yuan, C.; Subramanian, S. OMCD: OncomiR Cancer Database. BMC Cancer 2018, 18, 1223. [CrossRef] [PubMed]

363. Ushio, N.; Rahman, M.M.; Maemura, T.; Lai, Y.C.; Iwanaga, T.; Kawaguchi, H.; Miyoshi, N.; Momoi, Y.; Miura, N. Identification of dysregulated microRNAs in canine malignant melanoma. Oncol. Lett. 2019, 17, 1080-1088. [CrossRef] [PubMed] 
364. Zargar, S.; Tomar, V.; Shyamsundar, V.; Vijayalakshmi, R.; Somasundaram, K.; Karunagaran, D. A feedback loop between miRNA-155, Programmed cell death 4 and Activation Protein-1 modulates the expression of miR-155 and tumorigenesis in tongue cancer. Mol. Cell. Biol. 2019. [CrossRef] [PubMed]

365. Jung-Hynes, B.; Schmit, T.L.; Reagan-Shaw, S.R.; Siddiqui, I.A.; Mukhtar, H.; Ahmad, N. Melatonin, a novel Sirt1 inhibitor, imparts proliferative effects against prostate cancer cells in vitro culture and in vivo in TRAMP model. J. Pineal Res. 2011, 50, 140-149. [PubMed]

366. Zhang, Y.; Liu, X.; Bai, X.; Lin, Y.; Li, Z.; Fu, J.; Li, M.; Zhao, T.; Yang, H.; Xu, R.; et al. Melatonin prevents endothelial cell pyroptosis via regulation of long noncoding RNA MEG3/miR-223/NLRP3 axis. J. Pineal Res. 2018, 64, e12449. [CrossRef] [PubMed]

367. Jin, M.; Cao, M.; Cao, Q.; Piao, J.; Zhao, F.; Piao, J. Long noncoding RNA and gene expression analysis of melatonin-exposed Liaoning cashmere goat fibroblasts indicating cashmere growth. Naturwissenschaften 2018, 105, 60. [CrossRef] [PubMed]

368. Wang, T.H.; Wu, C.H.; Yeh, C.T.; Su, S.C.; Hsia, S.M.; Liang, K.H.; Chen, C.C.; Hsueh, C.; Chen, C.Y. Melatonin suppresses hepatocellular carcinoma progression via lncRNA-CPS1-IT-mediated HIF-1 $\alpha$ inactivation. Oncotarget 2017, 8, 82280-82293. [PubMed]

369. Chen, C.C.; Chen, C.Y.; Wang, S.H.; Yeh, C.T.; Su, S.C.; Ueng, S.H.; Chuang, W.Y.; Hsueh, C.; Wang, T.H. Melatonin sensitizes hepatocellular carcinoma cells to chemotherapy through long non-coding RNA RAD51-AS1-mediated suppression of DNA repair. Cancers 2018, 10, 320. [CrossRef] [PubMed]

370. Su, S.C.; Reiter, R.J.; Hsiao, H.Y.; Chung, W.H.; Yang, S.F. Functional interaction between melatonin signaling and noncoding RNAs. Trends Endocrinol. MeTable 2018, 29, 435-445. [CrossRef] [PubMed]

371. Fan, Z.; Zhao, M.; Joshi, P.D.; Li, P.; Zhang, Y.; Guo, W.; Xu, Y.; Wang, H.; Zhao, Z.; Yan, J. A class of circadian long non-coding RNAs mark enhancers modulating long-range circadian gene regulation. Nucleic Acids Res. 2017, 45, 5720-5738. [CrossRef] [PubMed]

372. Pereira Fernandes, D.; Bitar, M.; Jacobs, F.M.J.; Barry, G. Long non-coding RNAs in neuronal aging. Noncoding RNA 2018, 4, 12. [CrossRef] [PubMed]

373. Gomez-Verjan, J.C.; Vazquez-Martinez, E.R.; Rivero-Segura, N.A.; Medina-Campos, R.H. The RNA world of human ageing. Hum. Genet. 2018, 137, 865-879. [CrossRef] [PubMed]

374. Heward, J.A.; Lindsay, M.A. Long non-coding RNAs in the regulation of the immune response. Trends Immunol. 2014, 35, 408-419. [CrossRef] [PubMed]

375. Elling, R.; Chan, J.; Fitzgerald, K.A. Emerging role of long noncoding RNAs as regulators of innate immune cell development and inflammatory gene expression. Eur. J. Immunol. 2016, 46, 504-512. [CrossRef] [PubMed]

376. Murphy, M.B.; Medvedev, A.E. Long noncoding RNAs as regulators of Toll-like receptor signaling and innate immunity. J. Leukoc. Biol. 2016, 99, 839-850. [CrossRef] [PubMed]

377. Panda, A.C.; Abdelmohsen, K.; Gorospe, M. SASP regulation by noncoding RNA. Mech. Ageing Dev. 2017, 168, 37-43. [CrossRef] [PubMed]

378. Carpenter, S.; Fitzgerald, K.A. Cytokines and long noncoding RNAs. Cold Spring Harb. Perspect. Biol. 2018, 10, a028589. [CrossRef] [PubMed]

379. Wang, Z.; Zheng, Y. lncRNAs regulate innate immune responses and their roles in macrophage polarization. Mediat. Inflamm. 2018, 2018, 8050956. [CrossRef] [PubMed]

380. Yarani, R.; Mirza, A.H.; Kaur, S.; Pociot, F. The emerging role of lncRNAs in inflammatory bowel disease. Exp. Mol. Med. 2018, 50, 161. [CrossRef] [PubMed]

381. Memczak, S.; Jens, M.; Elefsinioti, A.; Torti, F.; Krueger, J.; Rybak, A.; Maier, L.; Mackowiak, S.D.; Gregersen, L.H.; Munschauer, M.; et al. Circular RNAs are a large class of animal RNAs with regulatory potency. Nature 2013, 495, 333-338. [CrossRef] [PubMed]

382. Hansen, T.B.; Jensen, T.I.; Clausen, B.H.; Bramsen, J.B.; Finsen, B.; Damgaard, C.K.; Kjems, J. Natural RNA circles function as efficient microRNA sponges. Nature 2013, 495, 384-388. [CrossRef] [PubMed]

383. Ebbesen, K.K.; Hansen, T.B.; Kjems, J. Insights into circular RNA biology. RNA Biol. 2017, 14, $1035-1045$. [CrossRef] [PubMed]

384. Shi, Z.; Chen, T.; Yao, Q.; Zheng, L.; Zhang, Z.; Wang, J.; Hu, Z.; Cui, H.; Han, Y.; Han, X.; et al. The circular RNA ciRS-7 promotes APP and BACE1 degradation in an NF-kB-dependent manner. FEBS J. 2017, 284, 1096-1109. [CrossRef] [PubMed] 
385. Su, C.; Han, Y.; Zhang, H.; Li, Y.; Yi, L.; Wang, X.; Zhou, S.; Yu, D.; Song, X.; Xiao, N.; et al. CiRS-7 targeting miR-7 modulates the progression of non-small cell lung cancer in a manner dependent on NF- $\mathrm{B}$ signalling. J. Cell. Mol. Med. 2018, 22, 3097-3107. [CrossRef] [PubMed]

386. Huang, H.; Wei, L.; Qin, T.; Yang, N.; Li, Z.; Xu, Z. Circular RNA ciRS-7 triggers the migration and invasion of esophageal squamous cell carcinoma via miR-7/KLF4 and NF-KB signals. Cancer Biol. Ther. 2019, 20, 73-80. [CrossRef] [PubMed]

387. Piwecka, M.; Glažar, P.; Hernandez-Miranda, L.R.; Memczak, S.; Wolf, S.A.; Rybak-Wolf, A.; Filipchyk, A.; Klironomos, F.; Cerda Jara, C.A.; Fenske, P.; et al. Loss of a mammalian circular RNA locus causes miRNA deregulation and affects brain function. Science 2017, 357, eaam8526. [CrossRef] [PubMed]

388. Srinivasan, V.; Cardinali, D.P.; Srinivasan, U.S.; Kaur, C.; Brown, G.M.; Spence, D.W.; Hardeland, R.; Pandi-Perumal, S.R. Therapeutic potential of melatonin and its analogs in Parkinson's disease: Focus on sleep and neuroprotection. Ther. Adv. Neurol. Disord. 2011, 4, 297-317. [CrossRef] [PubMed]

389. Willis, G.L. Parkinson's disease as a neuroendocrine disorder of circadian function: Dopamine-melatonin imbalance and the visual system in the genesis and progression of the degenerative process. Rev. Neurosci. 2008, 19, 245-316. [CrossRef] [PubMed]

390. Willis, G.L. The role of ML-23 and other melatonin analogues in the treatment and management of Parkinson's disease. Drug News Perspect. 2005, 18, 437-444. [CrossRef] [PubMed]

391. Hardeland, R. Melatonin and synthetic melatoninergic agonists in psychiatric and age-associated disorders: Successful and unsuccessful approaches. Curr. Pharm. Des. 2016, 22, 1086-1101. [CrossRef] [PubMed]

392. Rodella, L.F.; Favero, G.; Rossini, C.; Foglio, E.; Bonomini, F.; Reiter, R.J.; Rezzani, R. Aging and vascular dysfunction: Beneficial melatonin effects. Age 2013, 35, 103-115. [CrossRef] [PubMed]

393. Favero, G.; Franceschetti, L.; Buffoli, B.; Moghadasian, M.H.; Reiter, R.J.; Rodella, L.F.; Rezzani, R. Melatonin: Protection against age-related cardiac pathology. Ageing Res. Rev. 2017, 35, 336-349. [CrossRef] [PubMed]

394. Majidinia, M.; Reiter, R.J.; Shakouri, S.K.; Yousefi, B. The role of melatonin, a multitasking molecule, in retarding the processes of ageing. Ageing Res. Rev. 2018, 47, 198-213. [CrossRef] [PubMed]

395. Kireev, R.A.; Vara, E.; Viña, J.; Tresguerres, J.A.F. Melatonin and oestrogen treatments were able to improve neuroinflammation and apoptotic processes in dentate gyrus of old ovariectomized female rats. Age 2014, 36, 9707. [CrossRef] [PubMed]

396. Ding, M.; Feng, N.; Tang, D.; Feng, J.; Li, Z.; Jia, M.; Liu, Z.; Gu, X.; Wang, Y.; Fu, F.; et al. Melatonin prevents Drp1-mediated mitochondrial fission in diabetic hearts through SIRT1-PGC1 $\alpha$ pathway. J. Pineal Res. 2018, 65, e12491. [CrossRef] [PubMed]

397. Hadar, A.; Milanesi, E.; Walczak, M.; Puzianowska-Kuźnicka, M.; Kuźnicki, J.; Squassina, A.; Niola, P.; Chillotti, C.; Attems, J.; Gozes, I.; et al. SIRT1, miR-132 and miR-212 link human longevity to Alzheimer's Disease. Sci. Rep. 2018, 8, 8465. [CrossRef] [PubMed] 